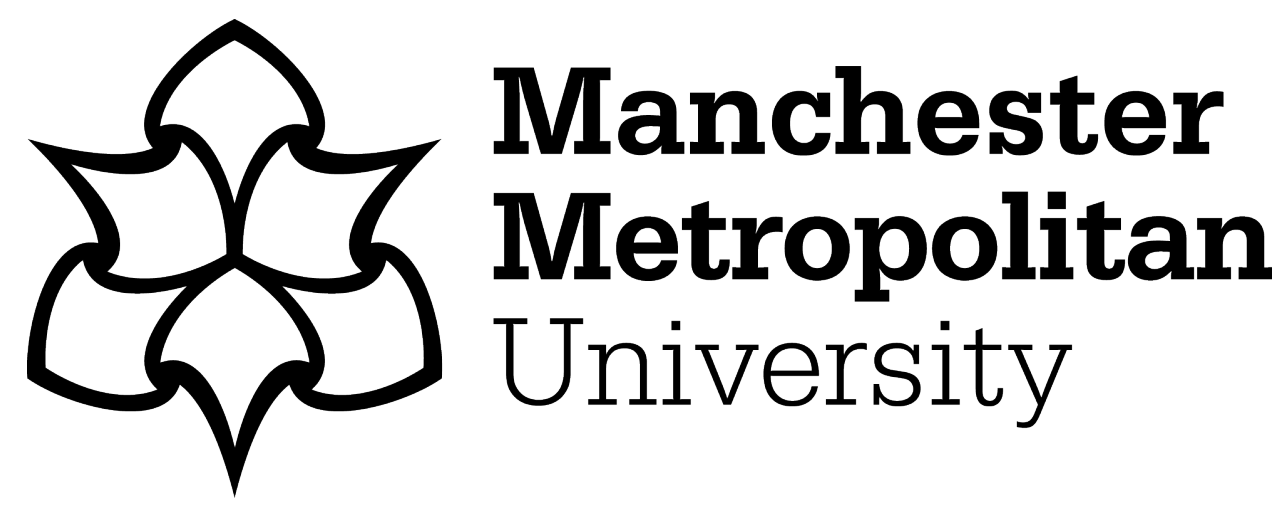

Brook, Richard ORCID logoORCID: https://orcid.org/0000-0003-4215-3091 (2020) The National Computing Centre: "White Heat", Modernization and Postwar Manchester'. Journal of the Society of Architectural Historians, 70 (4). pp. 438-458. ISSN 0037-9808

Downloaded from: https://e-space.mmu.ac.uk/624063/

Version: Published Version

Publisher: University of California Press

DOI: https://doi.org/10.1525/jsah.2020.79.4.438

Please cite the published version 


\title{
The National Computing Centre: "White Heat," Modernization, and Postwar Manchester
}

\author{
RICHARD BROOK \\ Manchester School of Architecture
}

$\mathrm{T}$ he creation of Britain's National Computing Centre (NCC) was publicly announced by Frank Cousins, the first minister of technology in Prime Minister Harold Wilson's Labour government, in March 1965. ${ }^{1}$ The Ministry of Technology (MinTech) was created as Wilson took office in October 1964, and it signaled his administration's commitment to his 1963 vision of an ultramodern Britain "forged in the white heat [of a scientific] revolution." The phrase "White Heat" became synonymous with Wilson's government and is popularly used to characterize the scientific and technological boom of mid-1960s Britain. Wilson's vision of economic security by means of technological advancement was central to the Labour Party election manifesto of 1964. Manchester, popularly heralded as the birthplace of modern computing, was announced as the location for the NCC in December 1965. The story of the NCC's conception and development is one of initial political urgency followed by almost a decade of little forward movement. A small temporary building was hurriedly erected from a design by the UK Atomic Energy Authority, after which the UKAEA submitted proposals for an administrative tower, which remained unbuilt. Eventually, the design of the permanent building was directed by John Seward of Cruickshank \& Seward, whose initial architectural proposals were drawn overnight between 4 and 5 May 1967. Construction was not completed until 1975 (Figure 1). The NCC's architecture embodied what many scholars today call "technopolitics," defined by historian Gabrielle Hecht as "the strategic practice

Journal of the Society of Architectural Historians 79, no. 4 (December 2020), 438-458, ISSN 0037-9808, electronic ISSN 2150-5926. (C) 2020 by the Society of Architectural Historians. All rights reserved. Please direct all requests for permission to photocopy or reproduce article content through the University of California Press's Reprints and Permissions web page, https://www.ucpress .edu/journals/reprints-permissions, or via email: jpermissions@ucpress.edu. DOI: https://doi.org/10.1525/jsah.2020.79.4.438. of designing or using technology to constitute, embody, or enact political goals."

The British technology sector was bound up with issues of rearmament during the Cold War, and it linked weaponry with computation. The race to develop nuclear missiles centered on three new technologies: rocket propulsion, uranium enrichment, and computation (first of missile trajectories, later of guidance systems). ${ }^{5}$ Research and development for each of these essential elements took place in the northwest of England. ${ }^{6}$ Connections between the region's research and industry and the buildings constructed to support the military and civilian applications of new technologies were necessarily hidden, sometimes in plain sight. The NCC was one small part of a regional military-industrial complex that operated for decades in a "semi-secret entanglement" with civil operations. ${ }^{7}$

In Britain, new construction for explicitly military purposes was winding down by 1960 as the geographic focus of the Cold War shifted to parts of the developing world. Nonetheless, the Soviet threat still informed British national policy. Government expenditure on rearmament during the postwar period outstripped spending on other national objectives. ${ }^{8}$ Archaeologists Wayne D. Cocroft and Roger J. C. Thomas have suggested that Wilson's Labour manifesto was partly informed by the achievements of the Conservative administration in the preceding decade. ${ }^{9}$ In this essay, I, too, challenge the narrative that a modernizing agenda of "White Heat" was exclusively Wilsonian, and, taking my cues from historian David Edgerton, I seek to understand the role of what he calls the "warfare state" in the wider built environment. ${ }^{10}$

To date, few studies have addressed militarism and computing in relation to architecture in the United Kingdom. Further, relationships among the postwar state, society, and technology remain contested in the historical literature, 


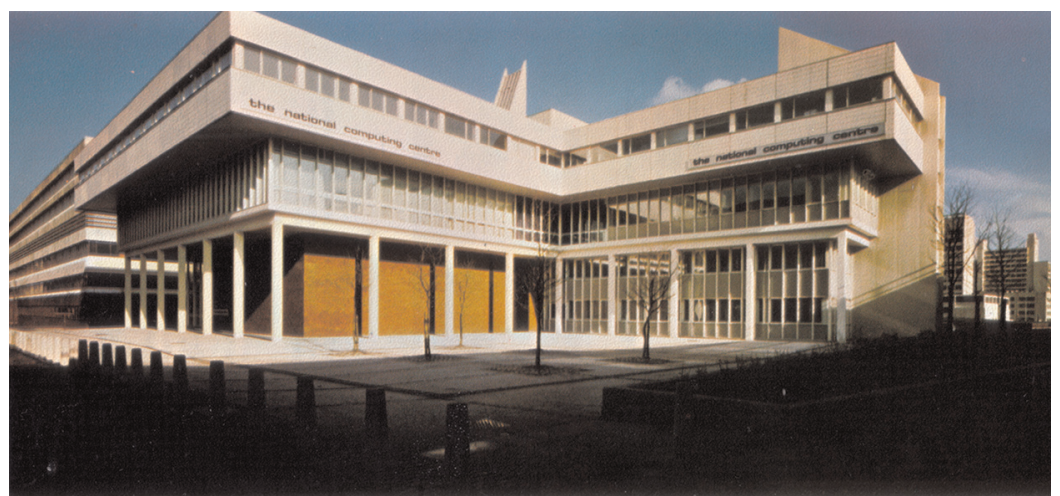

Figure 1 Cruickshank \& Seward, National Computing Centre, 1967-75 (private collection, used with permission). particularly in discussions of the role of military advances and civil applications. The popular view is that Conservative governments were more willing to fund defense, while Labour favored civil applications for research in the technology sector. ${ }^{11}$ Among scholars, the association between military technologies and advances in society has long been discussed. As early as the 1930s, Lewis Mumford situated "warfare and invention" and "military mass production" among his "agents of mechanization." " More recently, science historian Robert Bud introduced the idea of "defiant modernism," a mixture of national pride in British technological innovation and resentment at the country's loss of influence in the postcolonial, postwar era; Gabrielle Hecht, referring to France's postwar nuclear program, employed the term "technopolitics," as noted above. ${ }^{13}$ Each of these frameworks is useful in exploring the physical realization of architecture serving the British military-industrial complex.

Expenditures for Britain's nuclear program were often disguised as funding for civil applications and hidden behind the shifting ministerial structures of successive administrations, including that of MinTech. As historians Jonathan Hogg and Christoph Laucht note: "The institutional and official tone set by a small number of scholars has led to a significant proportion of atomic history being focused predominantly on government and elites. .. . Top down histories of the atomic age concentrate on Whitehall [Britain's center of government]." ${ }^{14}$ Hogg has suggested that "it is much more realistic to talk about the existence of complex, intertwined and localized nuclear cultures." 15 It is this regional clustering, of civil and military research and technology and its correlation with White Heat, that is of concern here.

With these four historical contexts in mind-the global Cold War, Britain's national modernizing agenda, the regional clustering of defense technologies, and the local expertise in computing-I employ the idea of a mainstream modern architecture in discussing the NCC building. "Mainstream modernism"-similar to what others have called "bread-and-butter" or "everyday" architecture-refers to that generally unremarkable, nonmonumental modern architecture found widely in Britain after the mid-1950s. ${ }^{16}$ While Reyner Banham disparagingly viewed such architecture as "routine," recent scholars have offered more positive readings. ${ }^{17}$ Architectural historian Alistair Fair, for instance, has described postwar British theaters as "embedded in the realities of practice rather than the narrow terms of avantgarde discourse." He argues that through these buildings, "it is possible to arrive at a more rounded understanding of the period's architectural history, one which includes a range of designers rarely considered by historians." 18 The concept of a mainstream modernism enables exploration of the manifold external factors acting on the procurement and production of various government buildings and allows us to consider them in relation to British social, cultural, political, and economic history. Studying Cruickshank \& Seward's designs for the NCC might thus permit an examination of the networks and the tangible relations between central government decision making, local planners' interpretations, and architectural outcomes. ${ }^{19}$

Small-scale private dwellings notwithstanding, most buildings are subject to multiple factors and not shaped exclusively by a single designer. For many of the building types ushered in by the British welfare state, building standards were developed and committees were convened to oversee construction. ${ }^{20}$ Yet despite burgeoning building control legislation, governmental design bulletins did not exist for weapons production facilities or computer centers. Such facilities housed novel technologies that demanded unique and specialized approaches. Buildings commissioned by the Ministry of Supply were not subject to local planning processes and were reasonably well funded. As one such building, the NCC was a bespoke project without precedent. It existed between the public and private sectors in its procurement and construction phases, and this status was mirrored in its architectural organization. ${ }^{21}$ Study of the NCC offers a particular view of the interplay among central and local government, public and private networks, and the interfacing of economic and physical planning that other projects of the welfare state do not provide. ${ }^{22}$ 
As opposed to presenting a formal or stylistic analysis that might view the NCC's architecture as derivative and diluted, characterized by "dreary stock solutions" and "faceless package deals," I will unpack the variety of commissions and procurement routes and the range and extents of public-private enterprise that surrounded the building's construction. ${ }^{23} \mathrm{I}$ will reveal the complex, interrelated networks that influenced the NCC's siting, mass, form, and materials as well as the relationships among various government departments, local authorities, private companies, public organizations, architects, developers, planners, and clients, as evidenced by policies, reports, finances, and schedules. I will examine the region as a productive unit and argue that the geographies, politics, and personnel involved had significant impacts on the production of the NCC's architecture. The architectural firm of Cruickshank \& Seward was but one of the many actors and elements that contributed to the building's evolution, and the architects' voices may seem diminished here. I view Cruickshank \& Seward, in effect, as a mediator in a negotiated practice between "abstract rationalities" and concrete realities. ${ }^{24}$

\section{Networks, Narratives, and the Selection of Manchester for the NCC}

The architects' professional experience was undoubtedly relevant to the design and production of the NCC building, but other actors and their networks were more significant in affecting the choice of site, the pace of development, and the eventual commissioning of Cruickshank \& Seward. Chief among these actors was Bertram Vivian Bowden. Bowden was educated at Chesterfield Grammar School and Emmanuel College, Cambridge. In the 1930s, he worked with Ernest Rutherford, coauthoring papers on the properties of gamma radiation. ${ }^{25}$ During the war he was posted to Washington, D.C., and the Massachusetts Institute of Technology to work on the development of radar. In the early 1950s, he led a British team in his role as principal scientific adviser to the Ministry of Supply's Telecommunications Research Establishment (TRE). ${ }^{26}$ On his return to the United Kingdom, Bowden joined the UK Atomic Energy Authority. ${ }^{27}$ His exposure to military technological research in higher education shaped his collaborative approach, including his eventual stewardship of the Manchester Municipal College of Technology (MMCT), which was later expanded to become the University of Manchester Institute of Science and Technology (UMIST). In 1964-65, Bowden served in Harold Wilson's Labour government as minister of state at the Department of Education and Science. His career is part of a larger story that illustrates how policy, personnel, finance, and technology converged upon the city of Manchester.
Bowden was forty-two years old and leading the computer sales division at the Manchester-based electrical engineering firm Ferranti when he was appointed principal of MMCT in $1953 .{ }^{28} \mathrm{He}$ directed the college's expansion, its refocus on degree-level teaching, and its renaming as UMIST, while Arthur Gibbon, a partner at Cruickshank \& Seward, oversaw the new campus's design (Figure 2). UMIST was one of only two new chartered institutions of higher education in Britain focused on technological education and funded by the University Grants Committee from the mid-1950s onward (the other was Imperial College London). ${ }^{29}$ Its development was in advance of the Robbins Report (1963), which advocated for the general expansion of the higher education sector. ${ }^{30}$ This report signified the need for regionally based scientists and technologists to serve causes, such as the nuclear program, that were not publicly stated.

Numerous and varied histories have been written on the development of the computer. ${ }^{31}$ Most relevant here are the networks of personnel involved in that development, their genesis, and their location in Manchester. Bowden worked with Freddie Williams, Tom Kilburn, and Peter Hall for the TRE during World War II. ${ }^{32}$ Williams and his assistant Kilburn were electronic engineers who found themselves rapidly without purpose in August 1945, as hostilities drew to a close. ${ }^{33}$ They gravitated toward the University of Manchester, where Max Newman, a Cambridge-educated mathematician, became professor of pure mathematics in 1945. Newman appointed Williams as chair of the Electrical Engineering Department in November 1946, while Kilburn was "on loan" from the Ministry of Supply. ${ }^{34}$ By June 1948, the assembled group of mathematicians and electrical engineers achieved a global first in realizing Alan Turing's "stored programme" computing principle, in the machine now popularly known as Baby. ${ }^{35}$ Shortly afterward, Bowden and Hall took positions with Ferranti.

Atomic warfare was a powerful force shaping the British government's agenda in the late 1940s. ${ }^{36}$ The nation's global power and authority were diminishing even as its political elite sought to reverse this course. In the United States, the Atomic Energy Act of 1946 (known as the McMahon Act) denied Britain any further collaborative role in the development of atomic weapons. The Berlin blockade coincided directly with the successful operation of Baby, and, as the Cold War began in earnest, the British government prioritized the development of the computational power necessary to calculate atomic bomb implosions. "Control and funding" in the fields of aviation, nuclear power, and related technologies in military and civil contexts fell to the Ministry of Supply, which became the largest single funder of research in both domains. ${ }^{37}$ In October 1948, the Ministry of Supply asked Ferranti to help build a computer designed by Williams, Kilburn, and Newman, funded by the Ministry of 


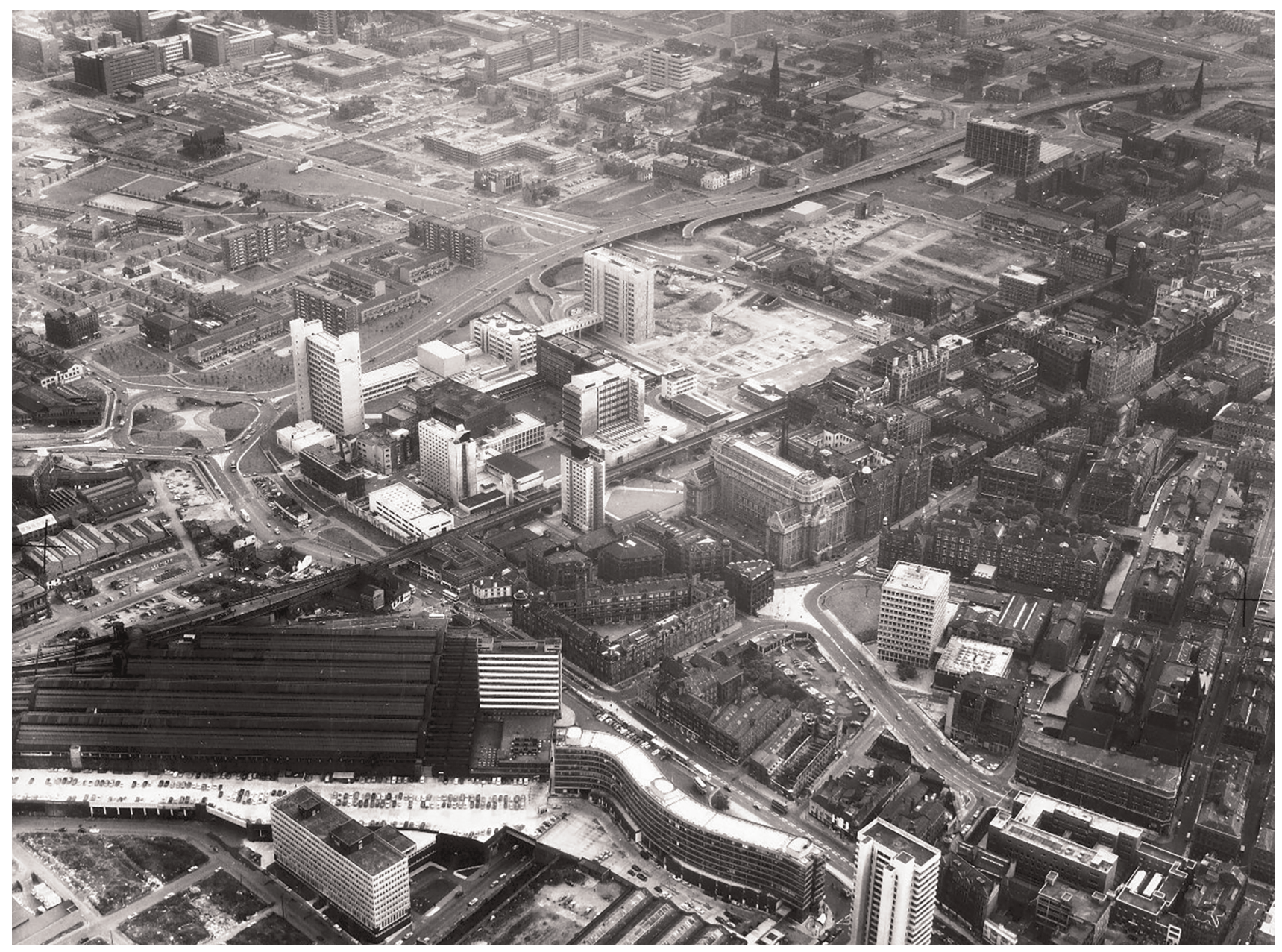

Figure 2 University of Manchester Institute of Science and Technology, 1967-75, aerial view, ca. 1970 (UPC/2/527, Digital Collections, University of Manchester).

Defence, and given technical support from the TRE. ${ }^{38}$ Bowden negotiated funding with representatives of various government ministries during his time at Ferranti. He informed the advisory committee to the National Research Development Corporation that he aimed to secure further monies for "a number of worthwhile research contracts" that were peripheral to the development of the computer, if the committee found this to be "in the national interest."

Bowden constructed strong narratives to support his broadly socialist agenda. In his 1953 book Faster Than Thought, he established the idea that Britain, and Manchester in particular, stood at the center of the computer's historical development. ${ }^{40}$ His interest in centering new technologies in Manchester was both public-spirited and privately endorsed, as such technologies provided the foundation for the growth of both education and commerce in the city. The networks with which Bowden was engaged varied over time. His work with Rutherford at Cambridge associated him with Newman and physicist Patrick Blackett in the 1930s. His role at the TRE with Williams and Kilburn took him to Washington and MIT in the 1940s. His local industrial networks in the 1950s connected these earlier encounters, forged his path as an educator, and ultimately led to his ministerial post in the 1960s. ${ }^{41}$ Bowden was not only able to influence histories but also had the capability and inclination to lobby government for support. His political adeptness no doubt contributed to his eventual appointment to a cabinet position, which coincided with the creation of MinTech in 1964.

One year earlier, Harold Wilson had famously captured the mood of the nation in his White Heat speech (titled "Labour's Plan for Science") at the Labour Party Conference in October $1963 .{ }^{42}$ There, he spoke of the need for research and development, the imperative of a scientific revolution, the importance of technological education, and the shared burden of the state and society in achieving these goals. ${ }^{43} \mathrm{He}$ played successfully on the notion that Conservative governments under Harold Macmillan and Sir Alec Douglas-Home had languished in an "Edwardian establishment mentality."44 This was resolutely misleading, as "the Conservative government embraced a rhetoric of modernisation," and "the 
Cabinets of both Macmillan and Douglas-Home contained a number of ministers with strong modernising tendencies." ${ }^{45}$ In fact, the policy objectives of the outgoing Conservative administration formed much of the intellectual agenda of Wilson's own campaign and cabinet.

The computer industry was one of the core interests of the newly formed MinTech. However, the possible applications of computation to business and research were unclear to most politicians. Even when considered retrospectively by those at its heart, the role of the ministry's computer division was described in ambiguous terms as "primarily, to encourage the use of computers, whenever they could be expected to increase the productivity of men, money or materials, and to offer advice on potential applications . . . and, secondarily, to assist the development of British computer manufacture." ${ }^{\text {46 }}$ This ambiguity signaled the hidden nature of an enterprise that was actually geared toward advancing military objectives. The expenditure, which was disguised as being directed toward civil research and development, aligned with Wilson's publicly stated objectives.

The United States, operating at the time from a much stronger economic base than the United Kingdom, undertook the majority of Western postwar investment in military technologies. Its first significant investments in computing were also attached predominantly to military objectives. ${ }^{47}$ France, Germany, and Britain realized that they had fallen behind in an important technological race. Crash programs and rapidly developed policies were deployed to close the gap. This was a situation in which traditional political binaries were relinquished; the overarching political culture of the postwar era and its underlying value system was a shared one. ${ }^{48}$ The rearmament program and the civil defense program were inseparable, and the technological culture of Britain was underpinned by investment in military contracts. ${ }^{49}$ Policy drove commissions for weaponry, the forced mergers of the Industrial Reorganisation Corporation, and the institution of new public-private partnerships. ${ }^{50}$ The Ministry of Supply became the de facto sponsor of these contracts, but, as Edgerton writes, there was also "a powerful, potentially commercially exploitable, overlap between new military and civil technologies, notably in aviation and nuclear power."51

Architectural historian Reinhold Martin has referred to the "aesthetic and technological extension" of the militaryindustrial complex in postwar U.S. architecture as "the organizational complex." ${ }^{, 2}$ In the 1940s and 1950s, large U.S. companies in the technology sector-General Motors, IBM, Bell Laboratories-employed high-profile architects and designers such as Eliel and Eero Saarinen, Eliot Noyes, and Skidmore, Owings \& Merrill to deploy networked logic in the design and assembly of their buildings and products. Meanwhile, British technology companies and related government agencies failed to attract equivalent levels of capital for architecture, and, amid the diminished economic and material resources of the postwar period, buildings for new technologies were viewed primarily as mere vessels for the activities they accommodated. The luxury of expressing corporate identity through built form was restricted by scarcity and diminished funding streams in a debt-ridden, resourcestarved, nationalized state. The drive to advance society and develop new technologies was thus curtailed, and technology companies and agencies were forced to optimize existing conditions, particularly in regard to construction.

Yet the desire to progress despite adverse conditions was accompanied by a distinct sense of pride, particularly in manufacturing towns. Traditional engineering skills and bespoke component manufacture remained prevalent in the production of high-tech objects in Britain. In certain sectors, new technologies were perceived as being of inferior quality if assembled from components whose manufacture was outsourced. ${ }^{53}$ Within Ferranti's computer division in Manchester, a city known for its engineering and manufacturing traditions, each part was made on-site to maintain quality standards, as was the case with earlier electrical technologies. This rather nostalgic pride may have been a necessary diversion in a society longing to be modern but forced by circumstances to depend on Victorian infrastructure.

\section{Building for the Computer}

Whether plans for the computer were civil or military, in this period research in Britain was situated mostly at universities. ${ }^{54}$ The experts Newman assembled at Manchester constituted one such research group, and parallel projects existed at Cambridge and Birkbeck College, London. ${ }^{55}$ There was some urgency in the computer's development, a fact reflected in the University of Manchester's commitment to construct a temporary building for the Computing Machine Laboratory. The laboratory was instituted in 1946, and the new building, designed by J. W. Beaumont \& Sons (1949-51), was hurriedly erected when it became apparent that Williams's memory solution was ahead of similar research being conducted at Princeton University in the United States. ${ }^{56}$ The world's first purpose-built building for computer research was a simple two-story structure of load-bearing brick, sparingly detailed across three structural bays-a basic container for the sophisticated, and urgent, technological work going on inside (Figure 3). ${ }^{57}$

Britain was slow to grasp the commercial possibilities of the computer, and as a result, its investment in the design of related products, branding, and buildings was sluggish. ${ }^{58}$ Things were moving more rapidly in the United States. An example of advanced U.S.-based design for military technology was the 1943 Armour Research Foundation Metals Building (now the Minerals and Metals Building) at the 


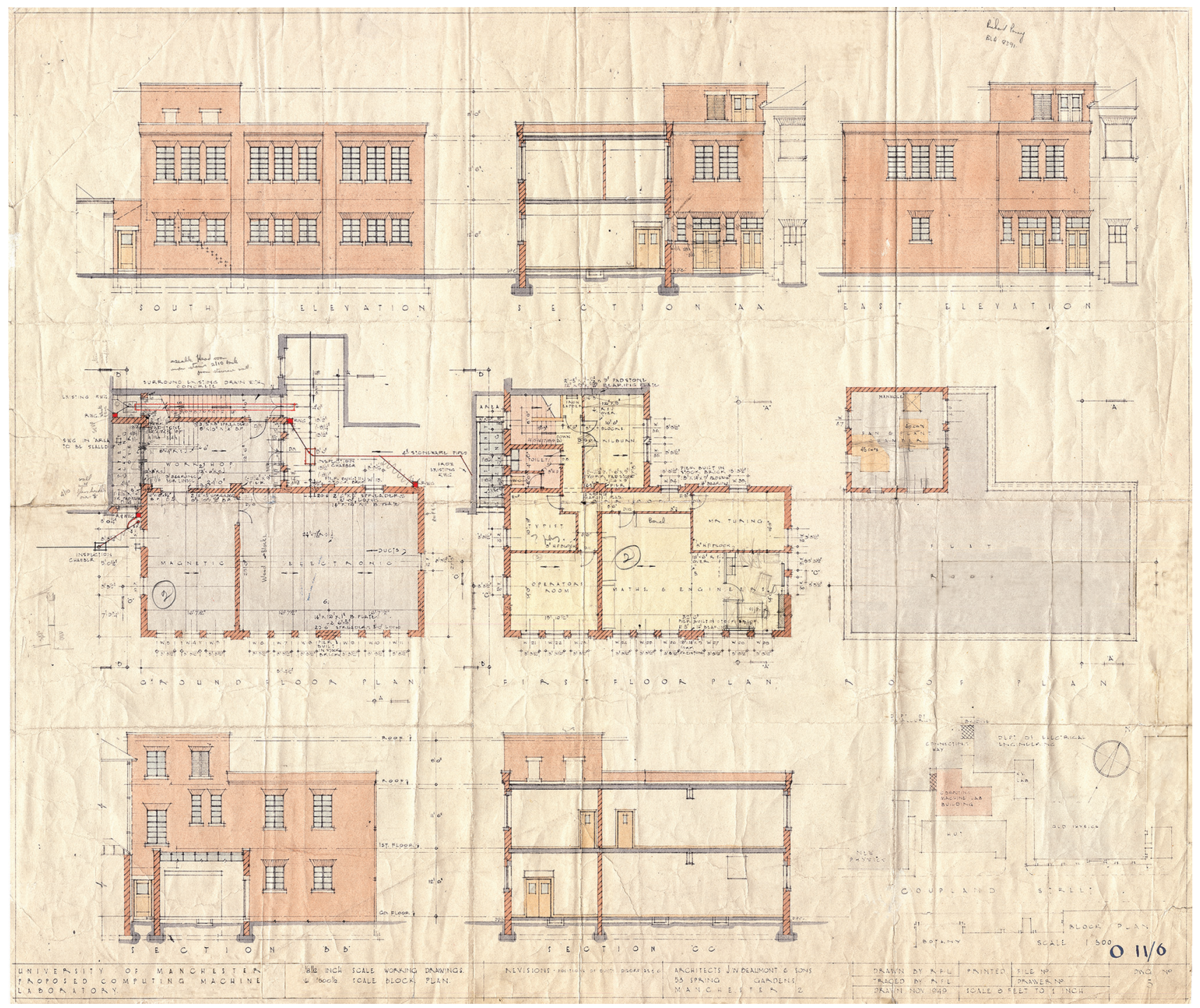

Figure 3 J. W. Beaumont \& Sons, proposal for the Computing Machine Laboratory, University of Manchester, 1949 (University of Manchester Estates Archive).

Illinois Institute of Technology campus in Chicago-Ludwig Mies van der Rohe's first building for IIT. This building's exposed-steel structure and glazed curtain wall lent it an industrial aesthetic that set the tone for IIT's modernist master plan and other campus buildings to follow. Mies was conscious of the relationship between his buildings and technology and was later described as having "tried to make an architecture for a technological society." $"$ His work on the IIT campus was well known and widely published in European architectural journals, but its influence was not evident in the schemes produced by local architectural practices for the University of Manchester, which remained relatively traditional. ${ }^{60}$

In 1964, an article in Architectural Record on Eliot Noyes's "building for machines" for Westinghouse, near Pittsburgh, was titled with a question: "The Computer Center: New
Building Type?"61 Noyes's scheme set a typological standard of situating computer rooms at the center of the plan and, because of the scale and loadings of what at the time were comparatively huge machines, on the ground floor. Spaces for computers were heavily serviced, and placing the computer hall centrally made environmental control more efficient. Most early computer applications were forms of advanced calculations, often related to payroll and other information that might be commercially sensitive. The enclosed nature of computer rooms, surrounded by other spaces and often without direct exterior access, thus offered enhanced security.

In Europe, it was the U.S.-based firm IBM that first brought technology and marketing together in its architectural commissions. Marcel Breuer designed IBM's French headquarters at La Gaurde (1957-62), employing a dynamic, double-Y-shaped plan with two of its wings raised on pilotis 
above the sloping site. The building's precast concrete façade marked the first use of the Breuer-Beckhard systeminvolving a variety of precast panels to create depth, decoration, and character-which was later deployed in buildings across the United States. ${ }^{62}$ IBM's first UK commission, in 1963, went to Farmer \& Dark, whose design for a lab and office building featured a squat eight-story tower with an adjoining single-story block set in the kitchen garden of a Georgian mansion outside Winchester. ${ }^{63}$ Ultimately, the application of new architectural materials and forms as a reflection of new technology and branded identity was delayed in Britain; it was not fully realized until 1971, when Norman Foster built the IBM Pilot Headquarters building at Cosham. ${ }^{64}$

\section{The Atomic Imperative and the Region}

The NCC had its genesis in a military context. Defenserelated research during World War II, by both Allied and German scientists, gave rise to the technologies that would define the global geopolitical landscape for the rest of the century: the nuclear bomb, the rocket, and the computer. The U.S. Atomic Energy Act of 1946, the first controlled nuclear explosion by the Soviet Union in 1949, and the outbreak of war in Korea in 1950 all contributed to making rearmament and civil defense central to British government activity. ${ }^{65}$ Welfare expenditure shrank and defense spending grew, feeding the warfare state. It was against this background of a continuous state of preparedness for military engagement that Britain's nuclear and computing industries were born.

Directed from London, the Manchester-based NCC emerged from an array of military-industrial facilities clustered in various regions. These were products of war. As early as 1935 , the British cabinet discussed the flight range of Luftwaffe bombers and the locations of munitions factories. ${ }^{66}$ Sites in northwest England were preferred because of their distance from mainland Europe. Of the forty-four Royal Ordnance Factories built during World War II, nineteen were retained after 1945 for the peacetime production of arms, including the nuclear program. ${ }^{67}$ As Julian Garratt observes, for production facilities, "a certain separation from centres of population had to be balanced against the accessibility of local labour. Within these constraints it was the proximity of industrial and academic organisations ... that led to the selection of North West England as the key location." ${ }^{, 68}$

The nuclear industry also required computers. Their use in civil and military applications was already wide and varied. Research and application went hand in hand. The connections between civil and military research were blurred, with the outcomes of either affecting the other, and research and commercial applications were similarly interconnected. The University of Manchester ran a research reactor at the UK Atomic Energy Authority site at nearby Risley, from which the uranium enrichment program was overseen and where the NCC had its first home. The Pegasus Mark I computer grew directly from the work of Manchester university researchers Kilburn, Turing, Williams, et al.; the Argus computer, built by Ferranti at its site in West Gorton, Manchester, came from research on control computers for guided weapons at Wythenshawe, just south of the city. This clustering of expertise and experience informed the decision to site the NCC building in Manchester.

In 1965, Gordon Black was appointed as the NCC's first director. ${ }^{69}$ At the time he already held two posts: professor of automatic data at UMIST and technical manager for computing at the UKAEA site at Risley. ${ }^{70}$ The governing council of the NCC first convened in May 1966, with members including Peter Hall (a colleague of Bowden, Williams, and Turing at the TRE and a director of International Computers and Tabulators, later International Computers Limited), Andrew St. Johnston (joint managing director of Elliot Automation), Wilfred Scott (managing director of English Electric-Leo-Marconi Computers), and Murray Laver (director of the computer division of MinTech). ${ }^{71}$ This group reflected the public-private enterprise envisaged by MinTech, one established with central government funding but ultimately intended to attract its own revenue from the services provided. As such, the NCC was founded as a limited company. ${ }^{72}$

The functions of the NCC were described in London's Guardian newspaper as "set[ting] up a national library of computer programmes and ... carry[ing] out research on the development of new programmes." ${ }^{73}$ The development of the NCC building ran parallel to the government-sponsored mergers that created International Computers Limited (once Europe's largest computer manufacturer) from parts of Ferranti's operation; this further reinforced Manchester's position as the home of UK computing.

The exact location and details of the NCC building's site were revealed in January $1966 .{ }^{74}$ Situated alongside a new urban aerial (elevated) motorway (Link Road 17/7, also known as Mancunian Way), the 2.6-acre site was adjacent to the site chosen for the British Broadcasting Corporation's new northern headquarters on Oxford Road (Figure 4). Originally, in Manchester Corporation's "Development Plan," which was approved in 1961, the NCC site was intended to form part of the Higher Education Precinct; in 1964, it was provisionally reserved for development by UMIST. ${ }^{75}$ Following a request from MinTech, however, Manchester Corporation and UMIST agreed that the location was "ideally situated for this important national project [the NCC building]. ${ }^{.76}$ The site's ready access to major transportation networks and its proximity to existing centers of corporate and university technological expertise were clear reasons for its selection. 


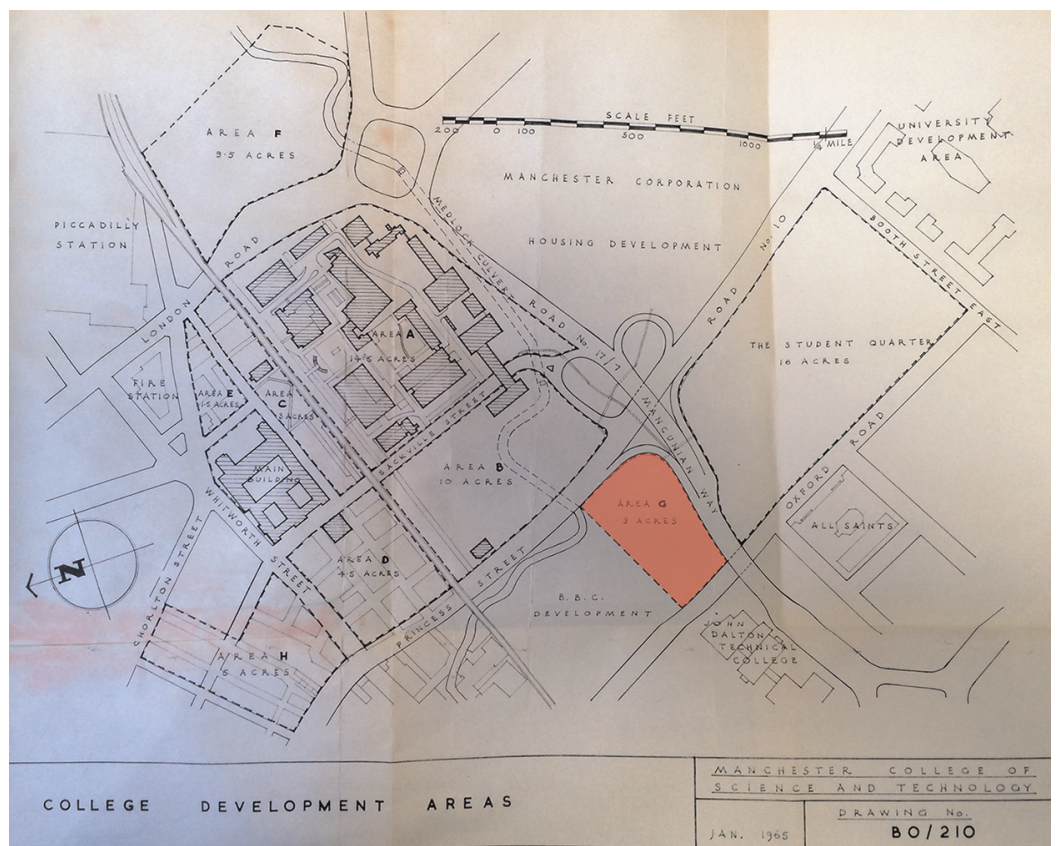

Figure 4 Development areas for the University of Manchester Institute of Science and Technology, with site for the National Computing Centre near lower right center (Area G), 1965 (TGB/2/5/3, University of Manchester Archives).
The site for the NCC building was at the intersection of two major Manchester Corporation planning initiatives-the Education Precinct and Mancunian Way. The Education Precinct, running south along Oxford Road, was first conceived as a part of the ambitious "City of Manchester Plan 1945," which recognized the university's value to the city's economy. ${ }^{77}$ The aerial motorway, a postwar highway project, connected the city's east-side manufacturing centers with its west-side docks. ${ }^{78}$ As television programming and audiences expanded, an adjacent site was allocated for the BBC's new northern headquarters. Finally, UMIST's focus on higher education initiatives meant that "further education" courses were moved to the new Municipal College of Technology, located across from the NCC site on Oxford Road (Figure 5). ${ }^{79}$ Thus, the NCC's prominent site stood firmly at the center of the new Manchester, embodying the technological aims and dynamism of the institution and its host city.

The contract for the first phase of the NCC building's construction was indicative of the urgent need to establish and situate the agency. In January 1966, before the NCC's governing council was convened or the limited company formed, MinTech officials proposed that the UKAEA act as architectural agent on their behalf. ${ }^{80}$ The NCC's Computer Building, design and construction of which were overseen by Atomic Energy Authority architect R. S. Brocklesby, was the National Computing Centre's first purpose-built architectural component-a near replica of the structure built by the UKAEA at Culham, just south of Oxford, in $1960 .{ }^{81}$ Brocklesby and his team of architects carried out the first phase "under considerable pressure," with only a scant design brief; the interior plans for the main building were "left until the new board [could] be consulted." 82 The building as completed was a spartan box with minimal fenestration, clad in dark-gray PVC-coated sheeting over a precast Bison concrete frame (Figure 6). Its two main floors accommodated offices and a plant room on the ground floor with the computer hall—surrounded by other spaces to protect against industrial espionage-tape rooms, and operator rooms above. A third floor featured large trusses that afforded space for wide plenum ducts to move the large volumes of air vital for cooling the computer. The supervisor's office looked through windows into the computer hall.

Construction of the Computer Building was already under way as proposals for a second phase were published in the press. Phase 2 called for an administration building that could be extended at a later date- "a tower building to take offices, computing libraries and conference rooms," five stories at first, expandable to twenty stories. ${ }^{83}$ At twenty stories this would be "the tallest building in the educational precinct... one of the focal points on Oxford Road next to Mancunian Way" (Figure 7). Precast units would be "modelled to give the building an interesting facade. ${ }^{\prime 4}$ No drawings are appended to the minutes of the Town Planning Committee in which the second phase is described, so it is impossible to know exactly how the proposed building was supposed to look.

Although it lacked a real program or design brief, the proposed twenty-story NCC administrative tower must have nonetheless satisfied the ambitions of Harold Wilson and his associates at MinTech. It would have provided a new symbol in a new district, representing new policies-the Wilson government's commitment to new technology and Manchester 
Figure 5 W. B. Heppell, Municipal College of Technology, Manchester, after completion of second phase, 1974, view from across Oxford Road, with National Computing Centre at left and BBC North headquarters at right (ZX-283, Manchester Metropolitan University Special Collections).

Figure 6 R. S. Brocklesby, original Computer Building for the National Computing Centre, 1966, with Mancunian Way at right (ZX-035, Manchester Metropolitan University Special Collections).

Figure 7 Building Design Partnership, model for proposed BBC North headquarters building, Manchester, 1969, with proposed National Computing Centre administrative tower (phase 2) and Mancunian Way at center right (Building Design Partnership).
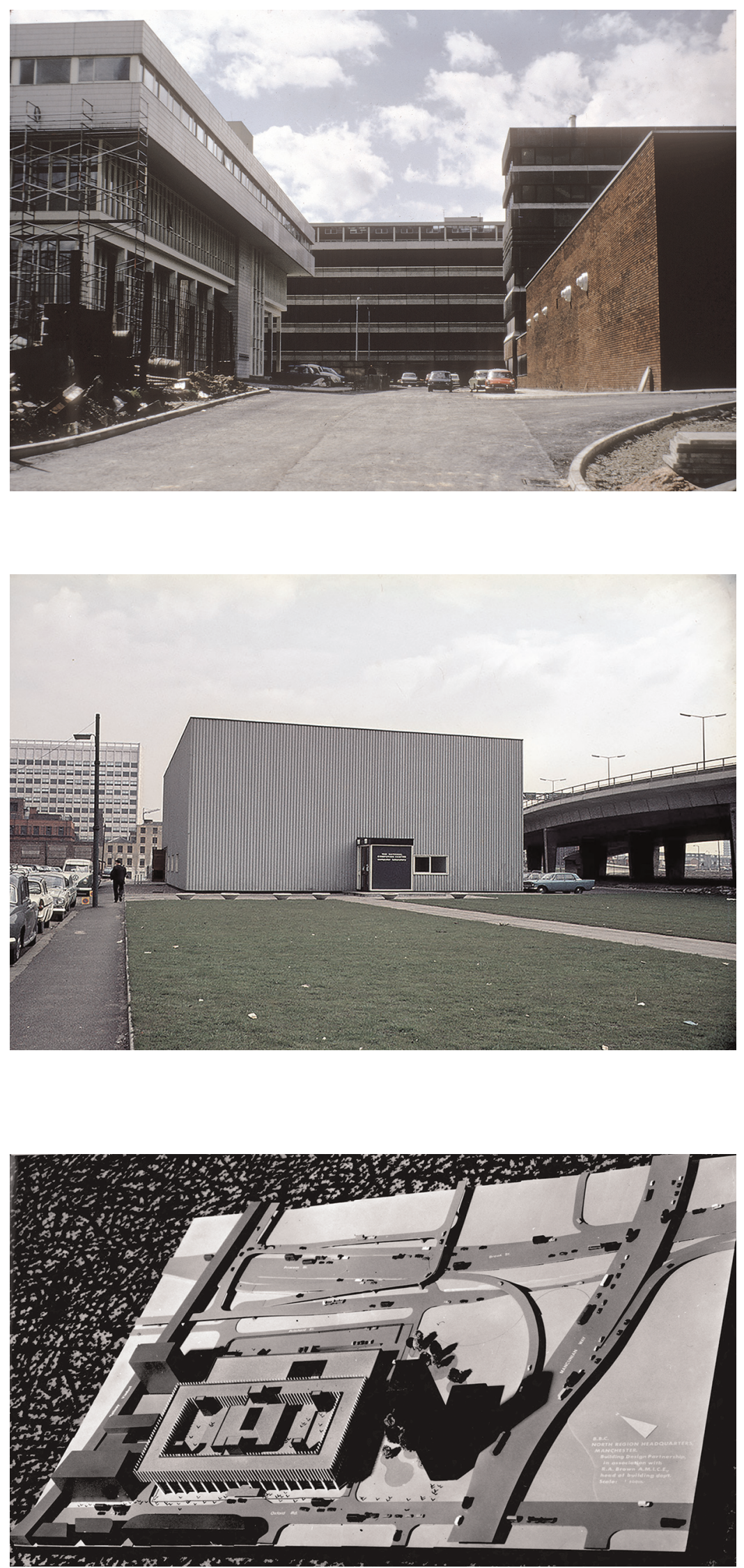
Corporation's dedication to establishing new industries in the knowledge and service sector to replace the shrinking manufacturing industries. Ultimately, however, the forces of capital and financial controls exerted by the Treasury, exacerbated by uncertainty regarding the NCC's specific functions, resulted in the tower's going unbuilt. ${ }^{85}$ Even after Harold Wilson revealed Cruickshank \& Seward's design in 1967, the arguments for a substantial NCC building, one that would achieve the needs of both politicians and the organization, were long drawn out. Manchester Corporation pressed the NCC for resolution about when its headquarters would be built, but, despite extended correspondence between MinTech and the Treasury, this was never made clear. ${ }^{86}$ The Treasury, questioning the logic of a building that seemed to be too big for its program, concluded that Manchester Corporation had put too much focus on prestige. ${ }^{87}$ The Treasury wrote to MinTech to warn the ministry that the project was a possible candidate for budget cuts in $1968-69$ and $1969-70 .{ }^{88}$

\section{Cruickshank \& Seward}

The NCC building eventually delivered by Cruickshank \& Seward was a direct response to these discussions and the anomalies between the figurative representation and programmatic requirements. It essentially wrapped around and enclosed Brocklesby's original Computer Building of 1966 (Figure 8). The enclosing building had to be sufficiently substantial in stature and appearance to fulfill the vision of a national flagship project, yet modest enough to avoid being a white elephant. Cruickshank \& Seward was considered a safe bet by MinTech as the firm had plenty of public-sector experience in university projects, most notably at $\mathrm{UMIST}^{89}$ During the postwar era, it was one of the preeminent architectural practices in Manchester, with a longer history than most other local firms. ${ }^{90}$

The partnership between Herbert William Cruickshank and Henry Thomas Seward began in Manchester sometime between 1919 and 1923, and the firm they founded remained active long after Cruickshank's death in $1935 .{ }^{91}$ Their decision to found a practice in Manchester is believed to have been based on the city's position between their hometowns (Aberdeen and Bournemouth) and its status as a major economic center. ${ }^{92}$ Secondhand accounts portray Cruickshank as principal designer and Seward as predominantly concerned with the business end of things. ${ }^{93}$ Information on the firm's work before 1945 is scarce, but the interwar years were apparently fruitful. During that period, when the practice designed a series of civic projects, some won through competition, Cruickshank \& Seward was generally successful, and that success continued after the war. In this regard, it is one of the few British architectural practices that bridged the $1939-45$ hiatus in production. ${ }^{94}$
Cruickshank \& Seward's early civic buildings, including work for colleges and hospitals across the country, were typically neoclassical in style; examples include the firm's 1925 extension to the Manchester Babies Hospital in Levenshulme and its 1935 design for Southport Technical College. ${ }^{95}$ Its early leisure and commercial buildings offered a clean, crisp, pared-down take on neoclassical and neo-Georgian styles, reducing details to subtle rebates on white ceramic tiles, glazed bricks, and faience. Cruickshank \& Seward buildings in Manchester that exemplify this approach include the Ritz Ballroom on Whitworth Street West (1928) and the John Line and Sons wallpaper shop on Peter Street (1938) (Figure 9). The use of the color white, originating in these early schemes, became a hallmark of the firm during the postwar years.

Following Cruickshank's death in 1935, Henry Thomas Seward employed senior partners while continuing as the firm's principal. The office was organized into teams, with the most prominent work going to Seward's son John and a talented young architect from Altrincham named William Arthur Gibbon (known as Arthur). ${ }^{96}$ John Seward and Arthur Gibbon studied architecture at the University of Manchester, which was well known for its faculty's expertise in classical and vernacular architecture. The two young architects were also influenced by modernists such as Alvar Aalto, Le Corbusier, and Oscar Niemeyer. Seward was particularly interested in Scandinavian design, and in the 1960s he and Gibbon visited Denmark and Finland, where they met Aalto at his studio in Helsinki. ${ }^{97}$ A Scandinavian influence, including the use of relatively organic forms, is clearly registered in a number of John Seward's designs, such as his chapel for the University of Manchester's Hulme Hall at Rusholme. ${ }^{98}$

As national policy fed the computer and higher education sectors, Cruickshank \& Seward began to obtain commissions in these fields. Beginning in the mid-1950s, the firm slowly and steadily built a reputation for good-quality modern design, with John Seward specializing in buildings for the industrial and technology sectors. His work for Ferranti built on that of his father, as when he employed the crisp white forms of the interwar years for a new administrative block at Hollinwood (1968) (Figure 10). Seward's team also designed a series of buildings for International Computers Limited and Sun Microsystems in West Gorton during the late 1960s and early 1970s (Figure 11). ${ }^{99}$

The specific circumstances of Cruickshank \& Seward's appointment to design the expanded NCC building are unknown. Harold Wilson visited Manchester on 5 May 1967 to open the first phase of the NCC project and the adjacent aerial motorway, Mancunian Way, at which time he made a speech in the Renold Building at UMIST (Figure 12). ${ }^{100}$ This building, designed and built under the direction of Arthur Gibbon, was among Cruickshank \& Seward's finest work. 
Figure 8 Cruickshank \& Seward, model for expanded National Computing Centre, ca. 1969, with Brocklesby's original Computer Building at center (Cruickshank \& Seward Archive,

Manchester Metropolitan University Special Collections).
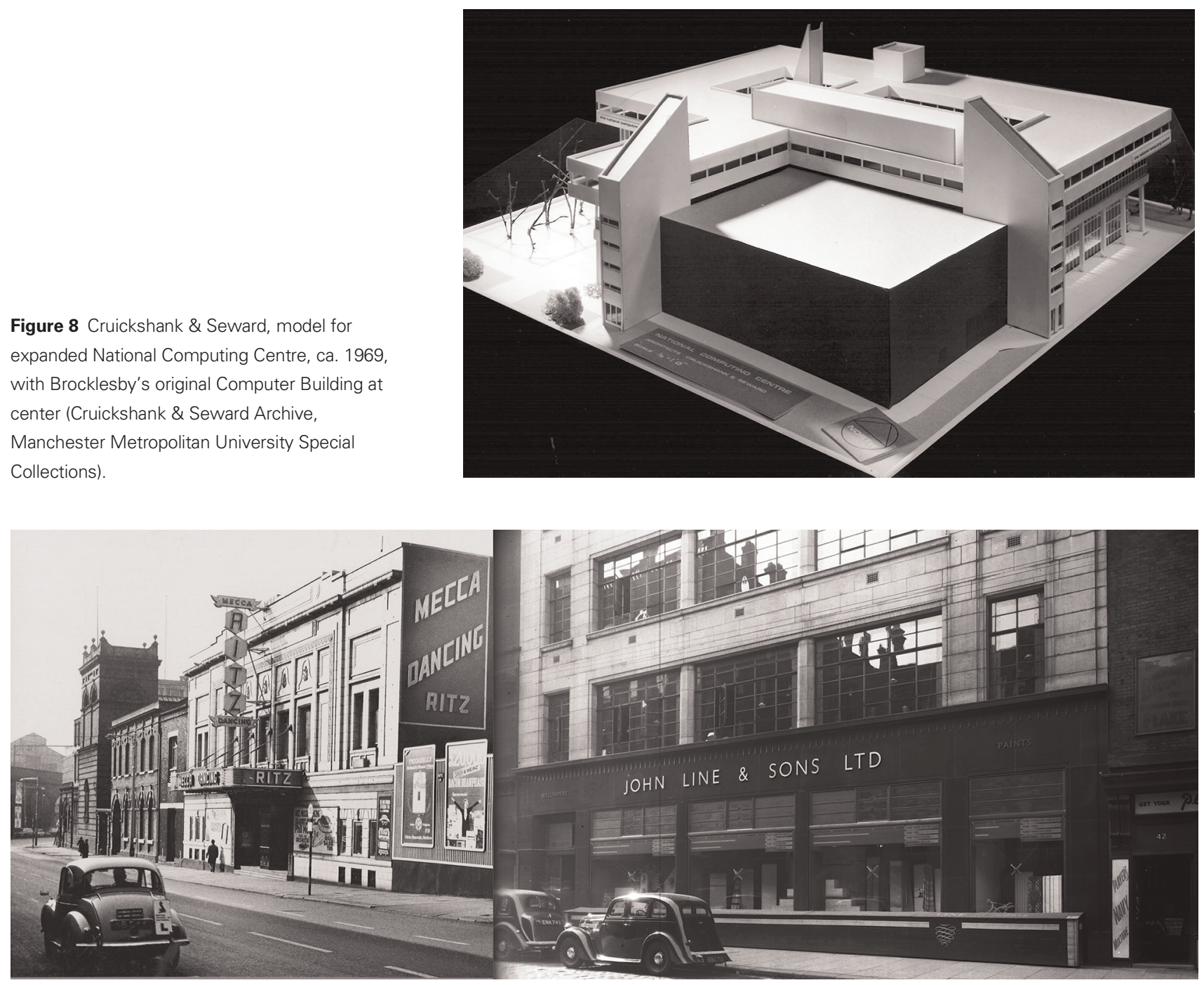

Figure 9 Cruickshank \& Seward, Ritz Ballroom, Manchester, 1928 (left), and shop for John Line and Sons, Manchester, 1938 (right) (m05514 and m74738, Manchester Local Image Collection).

Figure 10 John Seward for Cruickshank \& Seward, Ferranti administrative offices, Hollinwood, England, 1968 (Cruickshank \& Seward Archive, Manchester Metropolitan University Special Collections).

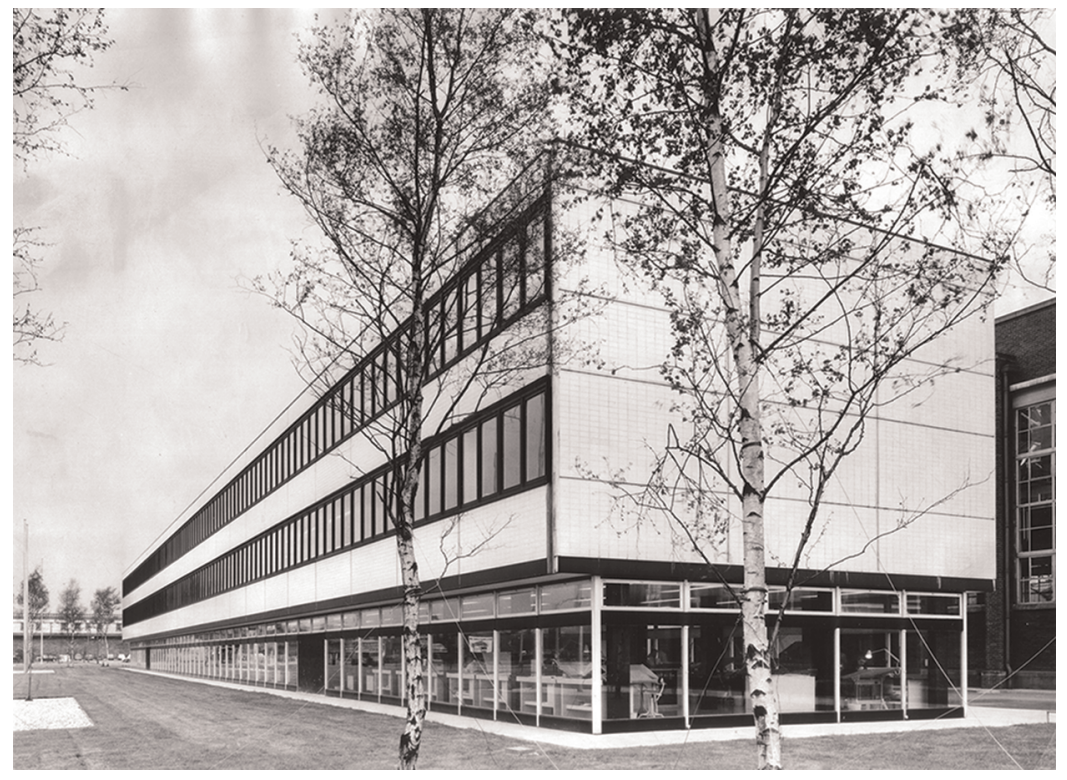




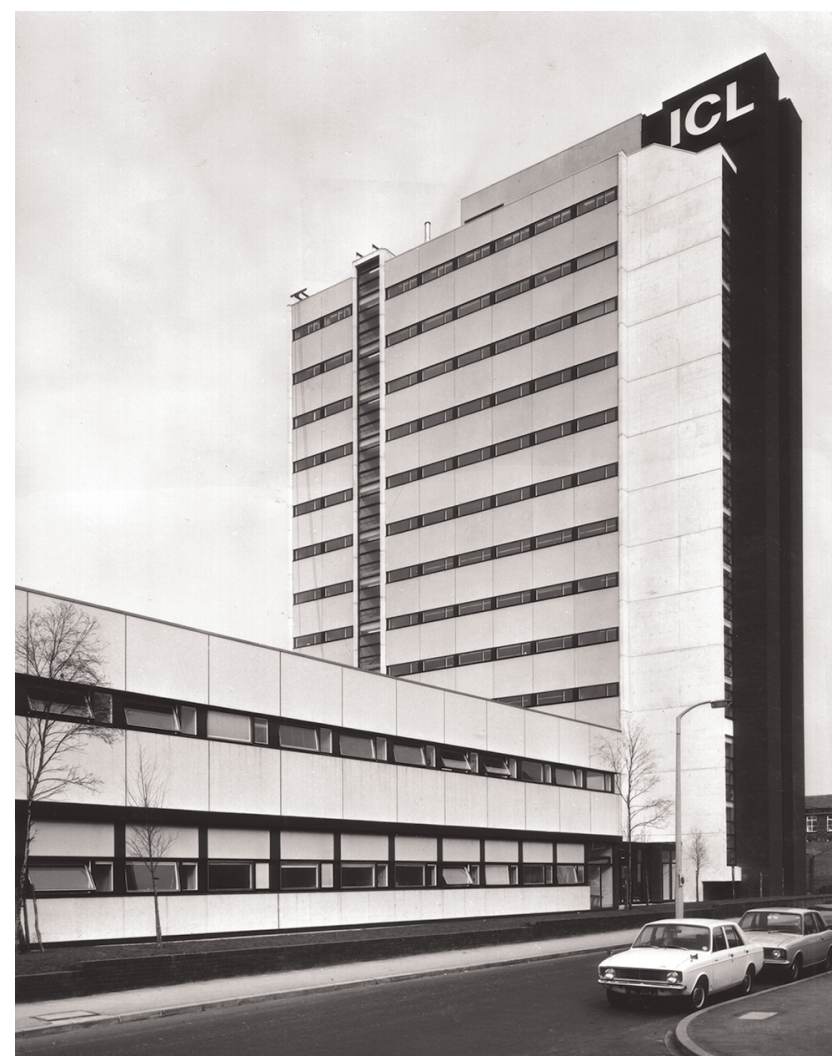

Figure 11 John Seward for Cruickshank \& Seward, International Computers Limited Building, West Gorton, England, 1971 (Cruickshank \& Seward Archive, Manchester Metropolitan University Special Collections).

It was one of the earliest podium-and-tower buildings in Britain, and it cleverly addressed a significant drop in site level between its north and south aspects. A generous, well-lit, timber-lined hall was created through the use of innovative prestressed, posttensioned bird's-mouth beams that carried the tower above and housed a band of clerestory glazing. The building's lecture theaters featured state-of-the-art acoustics designed by Hope Bagenal along with top-quality, Britishmade Rank projectors, which made the theaters technologically superior to other similar spaces in Manchester. Any one of them would have been a fine setting for a political speech on progress. Wilson might well have been impressed by the Renold Building and made aware of its designers by the NCC's leadership: Peter Hall was a friend of John Seward, and Bertram Vivian Bowden, Wilson's cabinet minister for education and science since 1964, was Arthur Gibbon's main patron. The backdrop to Wilson's speech was a painting of a scheme for the main NCC building, hurriedly prepared the night before by architect and painter Peter Sainsbury, after John Seward's drawings (Figure 13). By all accounts, Seward and his assistant Stan Barker retroactively composed the plans with reference to Sainsbury's painting. ${ }^{101}$
As an organization, the NCC was never large enough to have filled a twenty-story tower, yet it still required a building of more space and gravitas than the original Computer Building offered. According to the director of the Computer Division at MinTech, "The NCC [was] an important element in the Government's declared policy of seeking to promote a rapid increase in the use of computers."102 In Cruickshank \& Seward's earliest drawings, the plan's cruciform geometry created a lateral extension to the site's edges without producing too much floor space for the NCC's still-undetermined activities; the plan was as physically extensive as the site would permit, without committing to unusable or unprogrammed floor space (Figure 14). The original scheme from Brocklesby and his team was enveloped by the new building, the old building's exterior reclad with a dark-red rustic brick to match the lower walls of the new construction. The presence of the adjacent aerial motorway and rising BBC headquarters building meant that the new NCC scheme had to assume a particular height lest it be overshadowed by either of these flanking structures (Figure 15). The resulting design took the form of an inverted ziggurat, with the upper floors cantilevered out above the lower ones.

City Planning Officer John Millar wrote that Cruickshank \& Seward had "adopted a deliberately reticent architectural approach to avoid [the] building competing with the BBC Regional Headquarters immediately to the north." "103 It is unclear which BBC scheme Millar meant, although it may have been an unbuilt 1967 design by Building Design Partnership for a BBC North headquarters building (Figure 16). Included in Wilson Womersley's Education Precinct master plan, this, too, featured a cantilevered upper floor forming an exaggerated colonnade facing Oxford Road. ${ }^{104}$ The cantilevered upper floors were a reaction to the Education Precinct master plan, allowing for access to elevated walkways, which were proposed to connect the buildings to surrounding buildings and roads. This type of comprehensive planning characterized British inner-city renewal of the period and meant that buildings' appearance and form were often tied to, and influenced by, larger objectives (Figure 17). The inverted-ziggurat form also afforded the NCC building an almost overbearing muscular stature that belied its limited interior space yet satisfied the desire for an appearance of prestige.

Structurally, the NCC building was conventional, made of reinforced concrete. An orthogonal square grid echoing the building's underlying frame structure extended across the entire ground plan, with columns spaced on the nodes of the grid as required. The gridded, white-tiled façade suggested Cruickshank \& Seward's interwar-era work as well as computer-age motifs and futuristic sci-fi aesthetics. The grid also suggested themes of network and control, which were very much on the minds of MinTech personnel as they conceived 
Figure 12 Arthur Gibbon for Cruickshank \& Seward, Renold Building, University of Manchester Institute of Science and Technology, 1962 (author's photo).
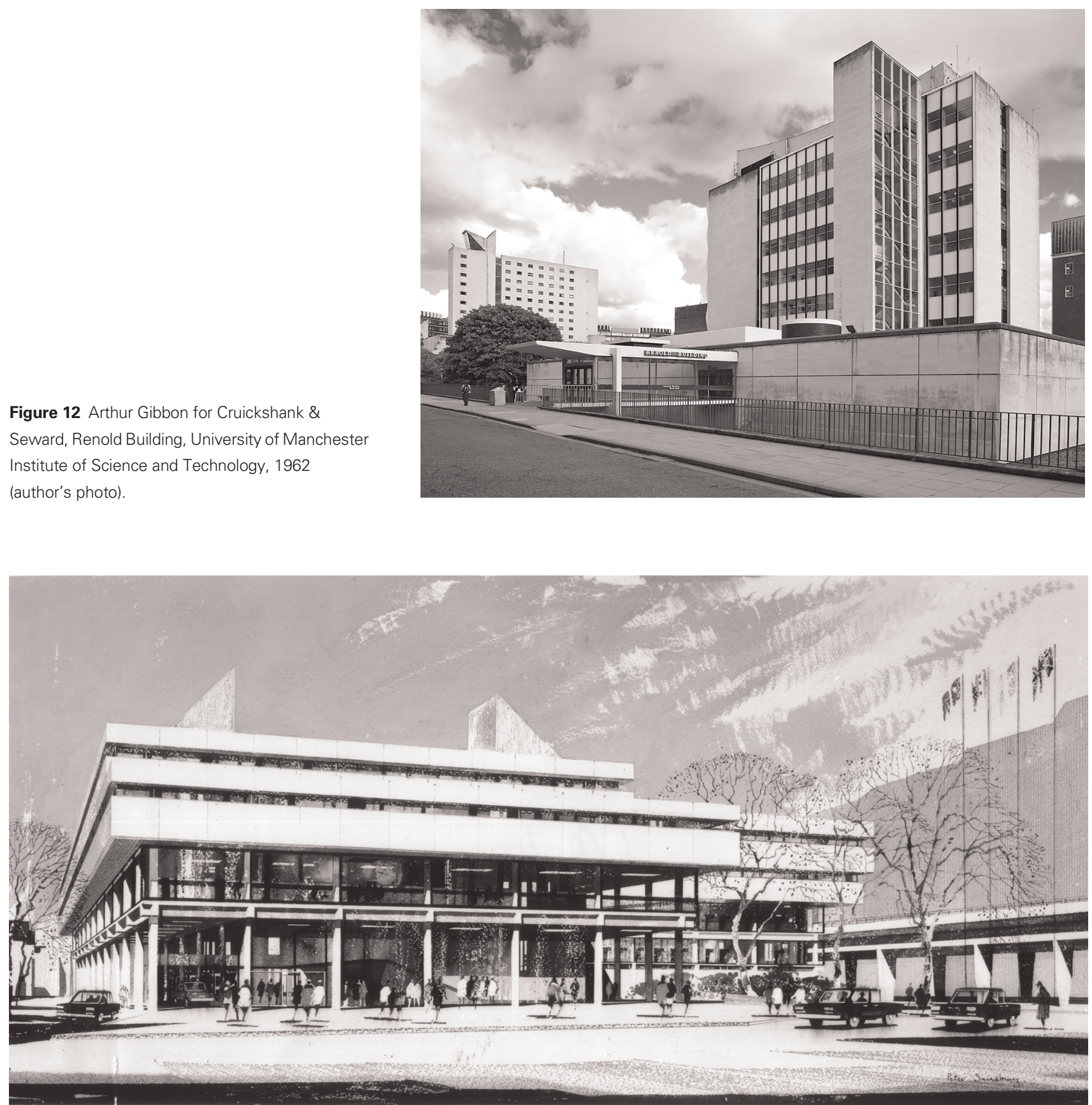

Figure 13 Peter Sainsbury after designs by John Seward, watercolor painting of the proposed National Computing Centre, 1967 (Cruickshank \& Seward Archive, Manchester Metropolitan University Special Collections).

the NCC and sponsored the computer industry. The ministry understood that one of the social consequences of the computer would be "much greater possibilities ... for government surveillance of the individual." 105

The logic of the gridded façade extended both outside to the hard landscaping and inside to the floor plan (Figure 18). Outside, small granite paving stones picked out the column line of the structure and extended it to the site's perimeter parking spaces on the north side. Inside, the ground floor, consisting mainly of circulation and service space save for a lecture theater, was arranged using the same grid; the upper floors were less rigidly organized and walls were mostly partitions. The only deviation from the orthogonal grid was the diagonally aligned landscape plan for an internal courtyard. This court was echoed by a water garden located above the lecture theater. Apart from the courtyard and the lecture theater, most 


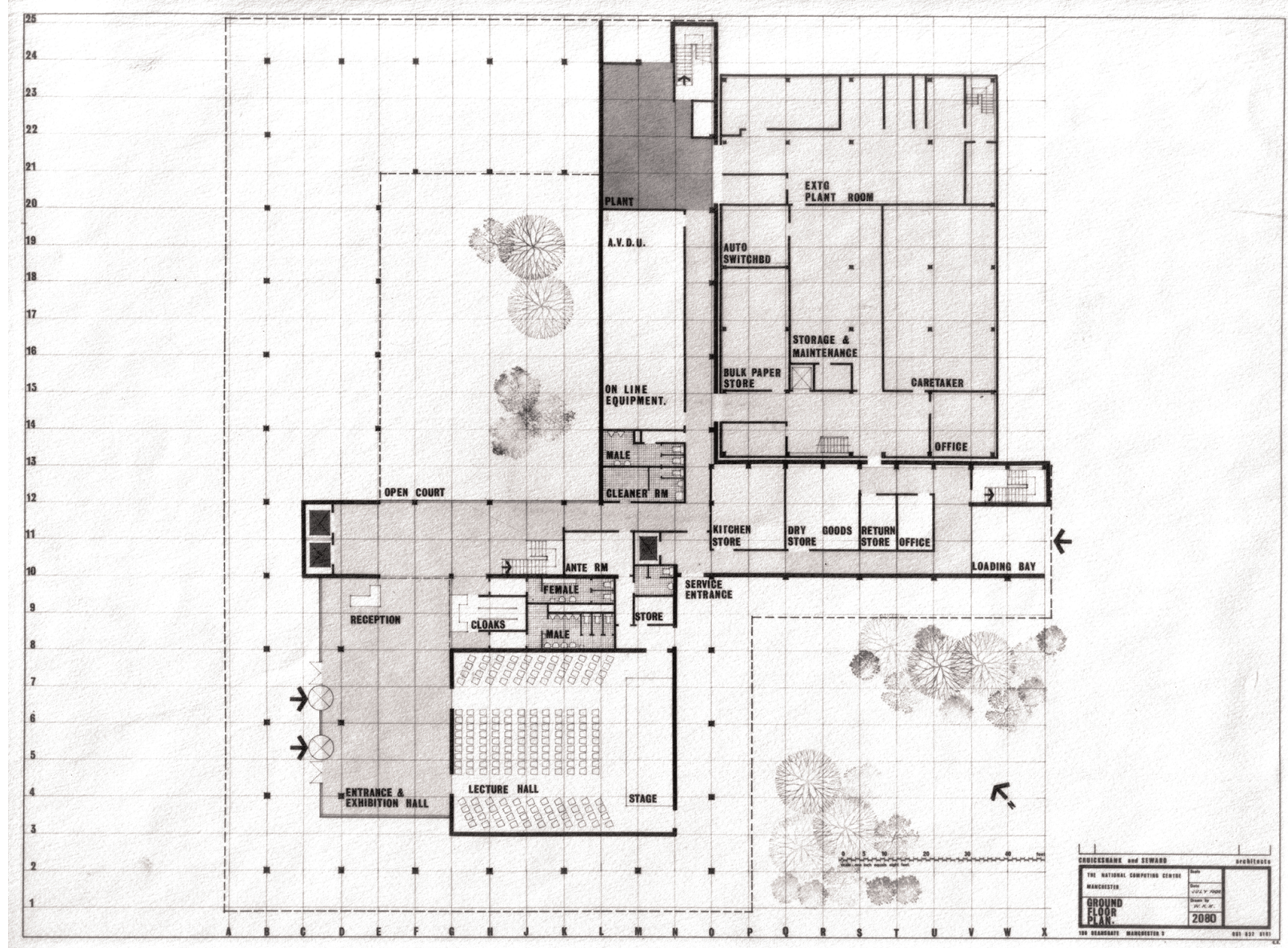

Figure 14 Cruickshank \& Seward, National Computing Centre, early version of the ground-floor plan, 1967, with Brocklesby's original Computer Building at top center right (Cruickshank \& Seward Archive, Manchester Metropolitan University Special Collections).

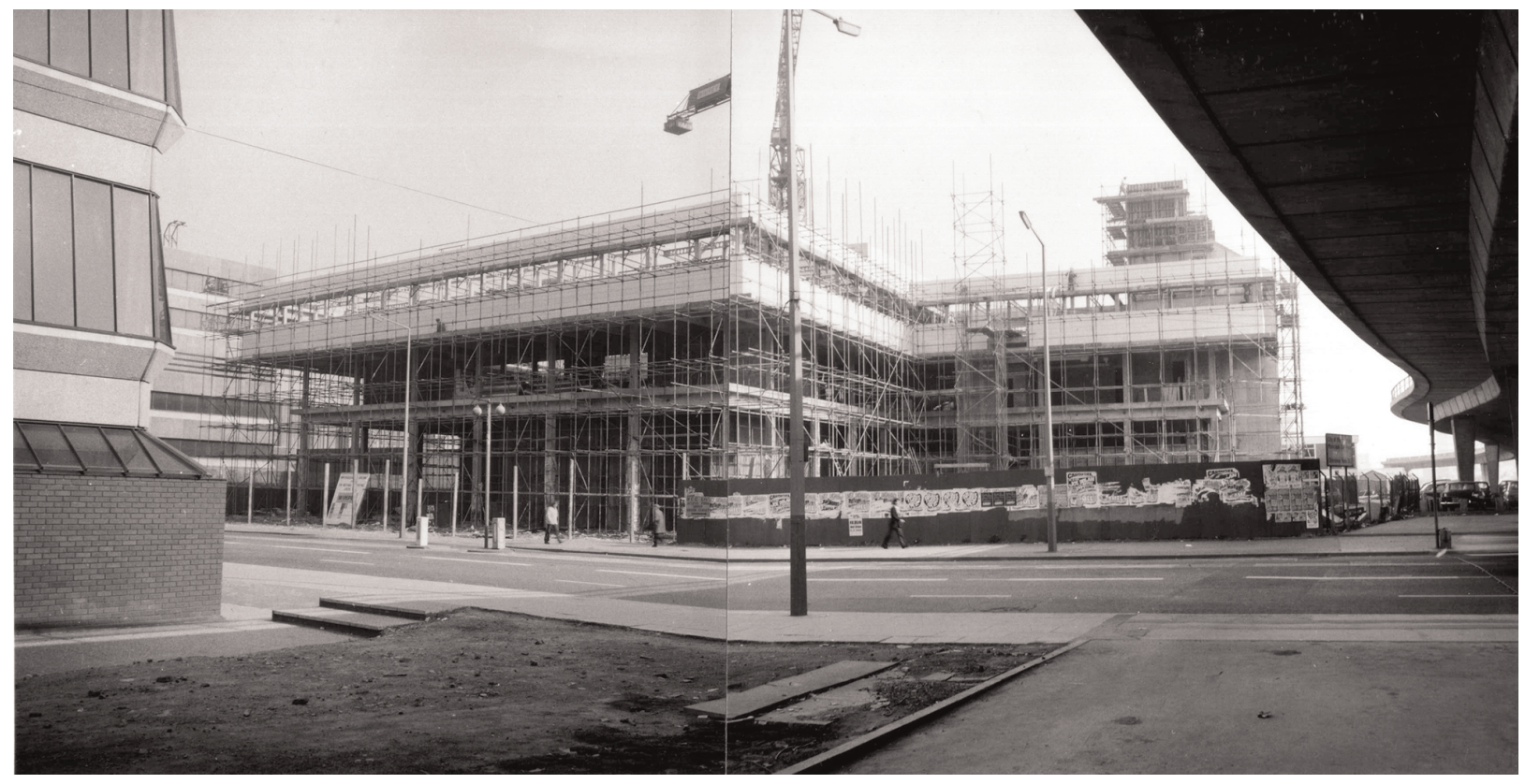

Figure 15 Cruickshank \& Seward, National Computing Centre, ca. 1973, construction view with Mancunian Way at right, Municipal College of Technology at left, and BBC North headquarters in the background (Cruickshank \& Seward Archive, Manchester Metropolitan University Special Collections). 


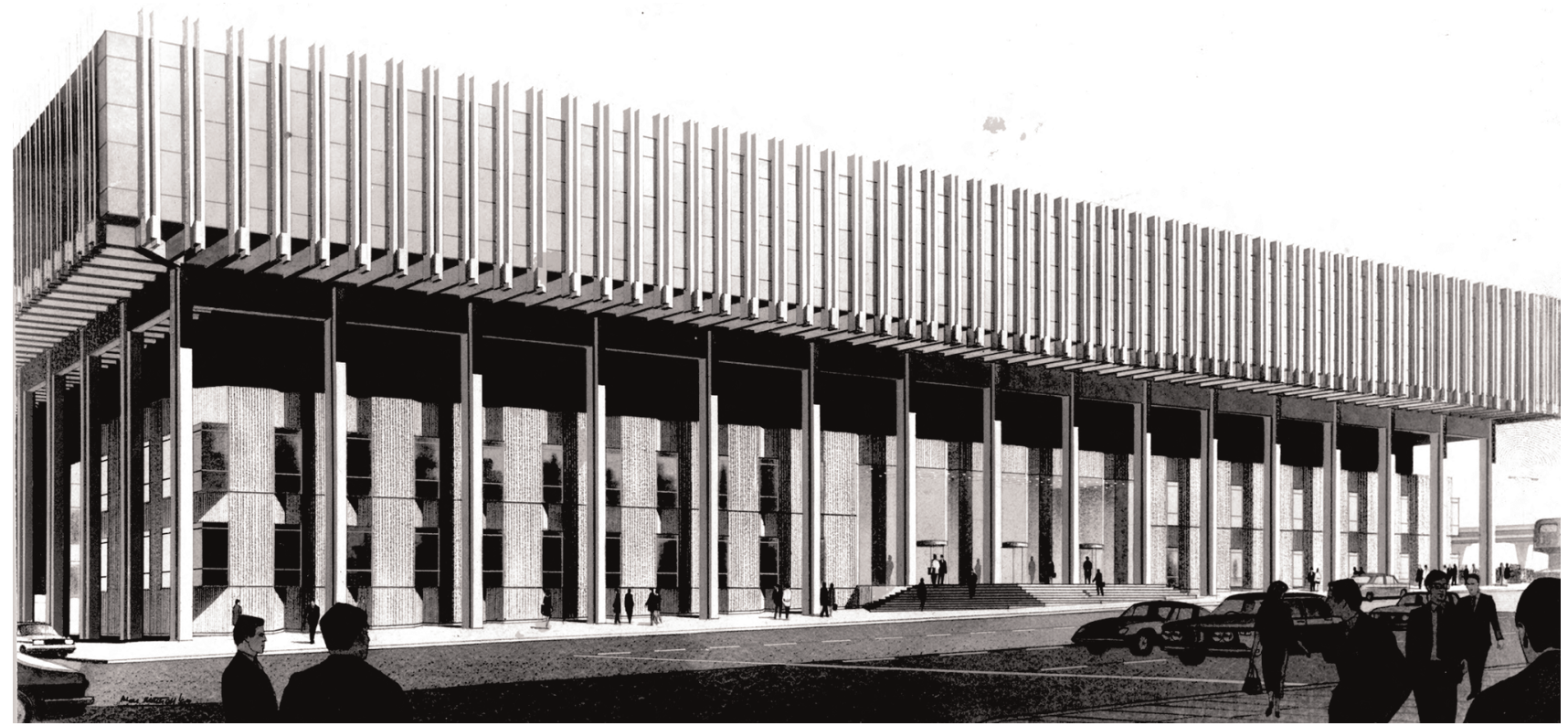

Figure 16 Building Design Partnership, proposal for BBC North headquarters building, 1969 (Building Design Partnership).

Figure 17 Wilson Womersley, master plan for Manchester Education Precinct, 1967 (private collection, used with permission).

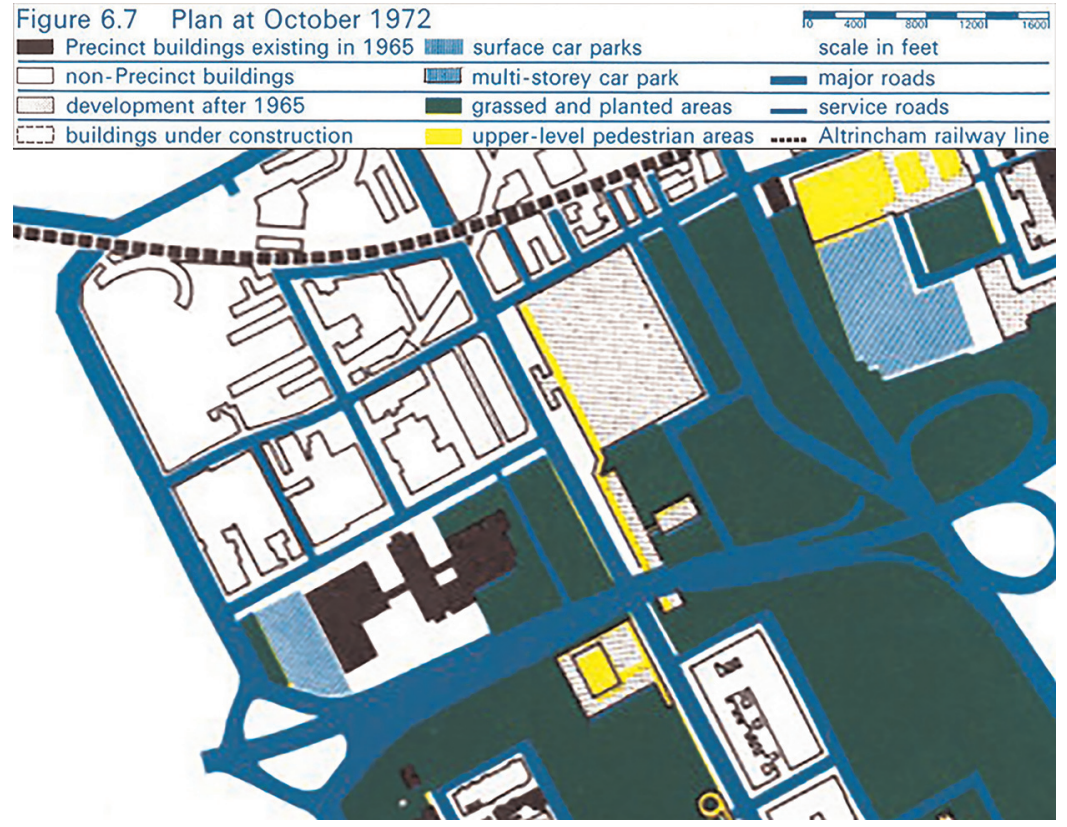

of the building's enclosed spaces were plain and conventional. Consequently, NCC brochures designed to market the building as a conference venue featured images of the courtyard, with employees enjoying the sunshine outside (Figure 19). Such marketing also pointed to the fact that, even at the NCC building's completion, its uses remained, in part, undetermined. Nonetheless, the building's gridded façade and stepped profile became the branded identity of the NCC, its relative drama on show while disguising a conventional interior-albeit one that named its meeting rooms and lecture theaters after the pioneering British computing machines: Atlas, Ace, Deuce, Leo, Mercury, Orion, and Pegasus. ${ }^{106}$

The NCC building represented a negotiation between central government objectives and local government projects. It was also an architectural representation of technopolitics, big enough for the site, big enough for Manchester 


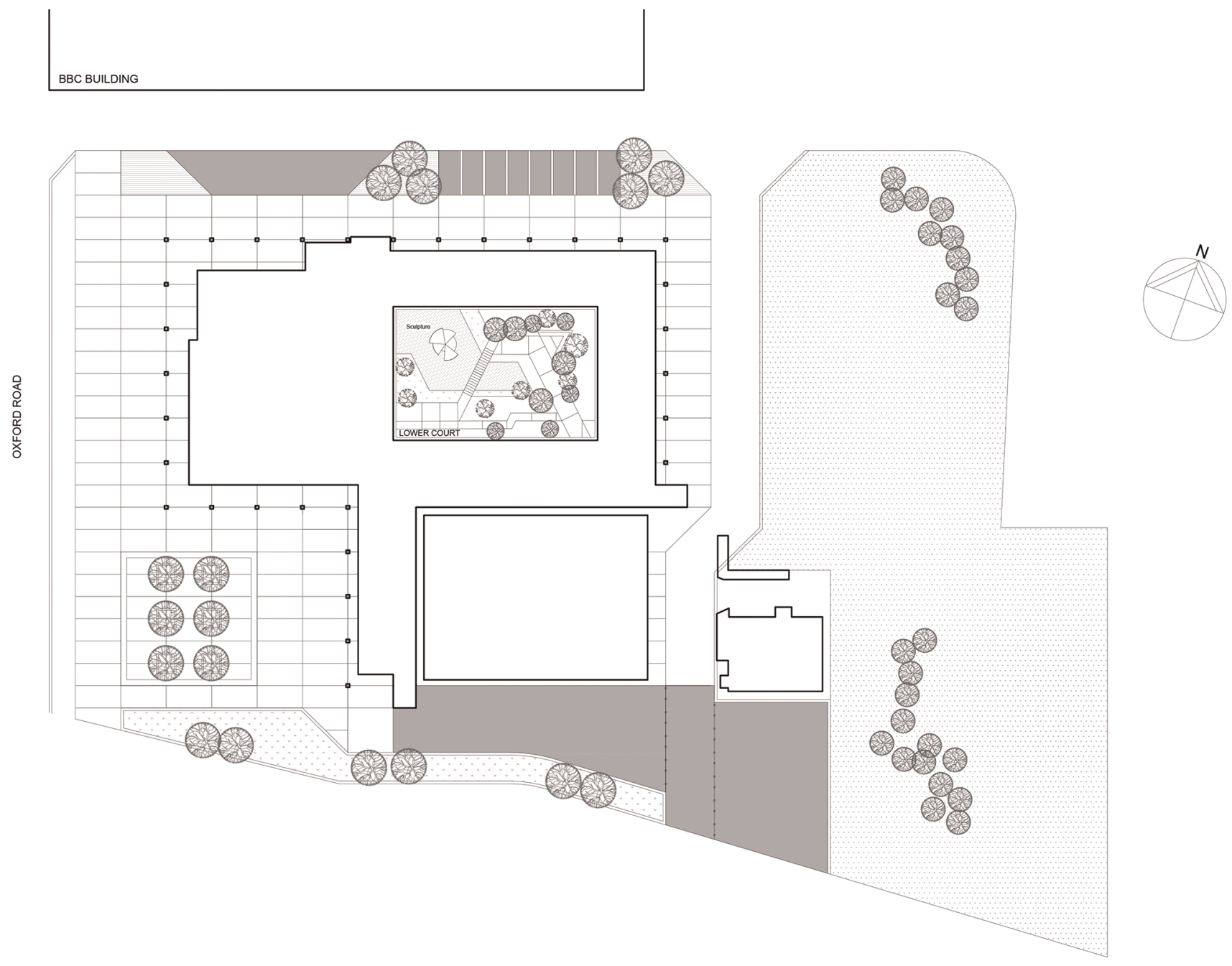

Figure 18 Derek Lovejoy \& Partners, landscape plan for National Computing Centre, 1971 (78018, Building Control Archives, Archives+, Manchester Central Reference Library; redrawn by author).

Corporation, and big enough for MinTech to appear credible when the building was finally opened in December 1975, ten years after the NCC was first established.

\section{Computing, a Conclusion}

The commission, design, and construction of the state-sponsored NCC building, spanning a decade when Britain was successively led by Labour and Conservative governments, somehow survived the typical culling by one administration of the previous one's pet projects. This may be attributed to the project's momentum, or it may point to a defense imperative never publicly stated. As Edgerton observes, "There is little linkage between the political salience of issues, and the scale and scope of the state's technological activity." ${ }^{107}$ Either way, the NCC building's mainstream modernism obviated simple political binaries.
The concept of mainstream modernism permits a reading of government-funded architecture beyond the politics of left and right—a political binary otherwise almost inevitable in a discussion of the twentieth-century state and its architectural production. It also provides a way to encounter the architecture of the 1960s and 1970s without resorting to stylistic assessment, in this case seeing the NCC building's ostensibly bland or diluted modernism as material evidence of the political interplay embodied in postwar Britain's infrastructural modernization.

National, regional, and local actors all had powerful impacts on postwar Manchester and its architecture. The NCC building was a manifestation of central government policy, yet its location in Manchester was a product of regional structures. The site was a crucial piece of Manchester Corporation's postwar urban schemes, requisitioned for national interests, while the building's form and materials were 


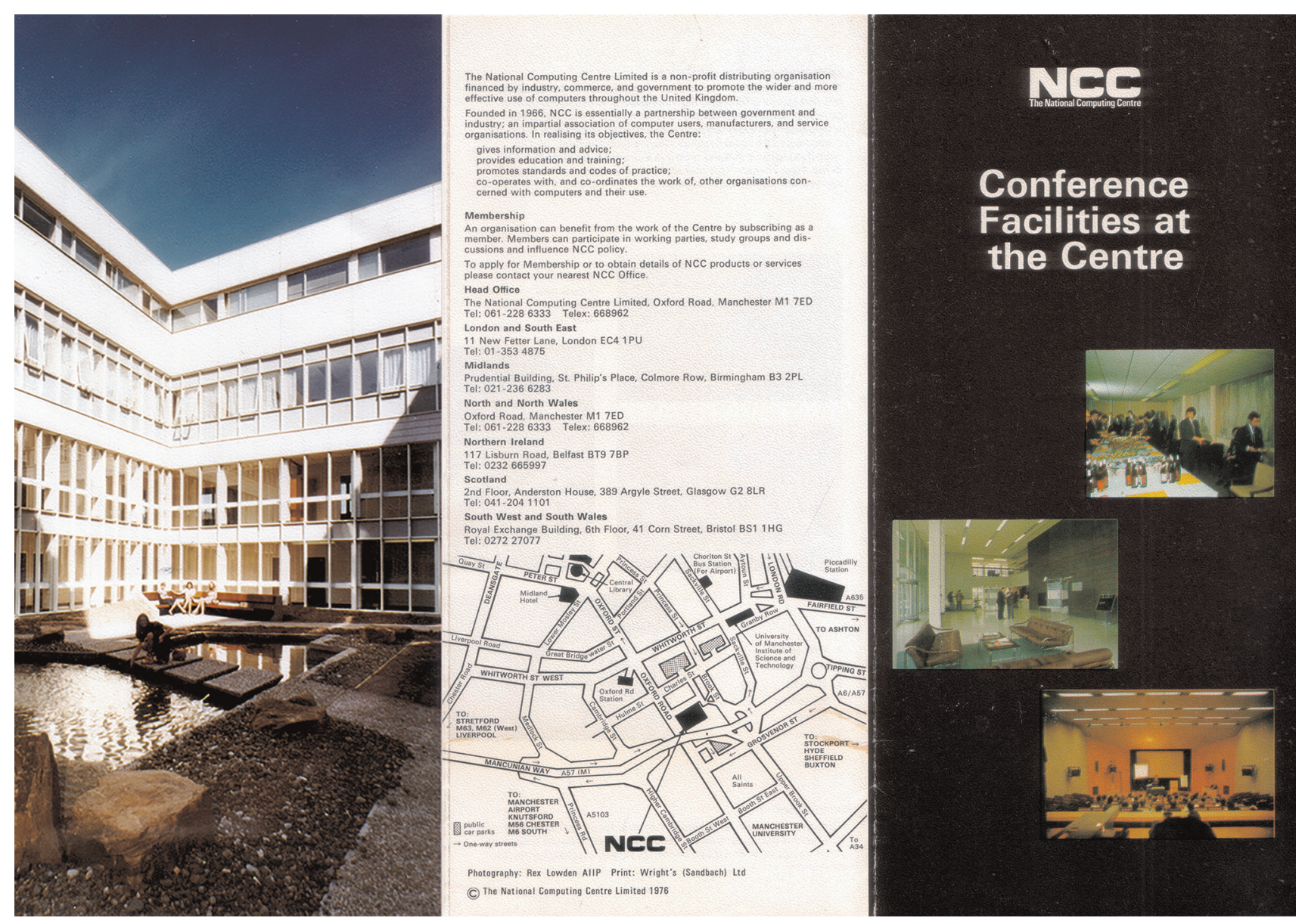

Figure 19 Brochure promoting conference facilities at the National Computing Centre, photo ca. 1975, with view of the NCC courtyard at left (private collection, used with permission).

influenced by the interplay between national and local policy objectives and infrastructures. The orbit of agents and the orientation of their networks toward Manchester began in the Telecommunications Research Establishment during the war. The NCC was given a home in Manchester because of the legacy of Turing, Williams, Newman, and Kilburn, which was, in turn, mythologized by Bowden, who perpetuated the idea of Manchester as the birthplace of the computer.

Describing the NCC building's design in relation to the regional military-industrial complex and the planning policy objectives of the local authority, and as a response to central government agendas, demonstrates how mainstream modernism can help us understand alternative scales over time. Further, the concept of mainstream modernism allows for a view of the state and its activities beyond those embodied by the oft-attached prefix of "welfare." It addresses questions of how we might consider the "differences between the exceptional and the everyday," and how analysis of the territories of state, region, city, site, and building can be variously productive. ${ }^{108}$

If the NCC building was a metaphor for the competencies and power of the Ministry of Technology and the rhetoric of
White Heat, the drawn-out process of its completion reflected the gestural nature of British policy. While the shining white structure stood prominently against a new horizon and signified increased investment in technology, its long development reveals an alternative picture of postwar architecture and its relation to policy and political objectives.

Richard Brook is an architect and historian whose research focuses on postwar mainstream and municipal modernism. He is the author of Manchester Modern and an adviser to the Manchesterbased Modernist Society. His recent funded projects include an examination of the intangible values of British postwar infrastructural landscapes. https://www.msa.ac.uk/staff/rbrook/

\section{Notes}

1. I would like to thank the anonymous reviewer who helped to shape my argument in this essay by offering thorough commentary on the manuscript. Keith Eggener's acutely focused editing cut through my many digressions and refined the final product. In terms of research, I am grateful to Mark Crinson, Isabelle Doucet, Anthony Gerbino, Martin Dodge, and Michael Hebbert, who supervised my doctoral thesis. My examiners, John Gold and Łukasz Stanek, tested my arguments and greatly assisted in their synthesis. Jonathan 
Aylen, James Sumner, Simon Lavington, and John Wilson all provided insightful comments on earlier drafts of this article. Jan Hicks and Jan Shearsmith from the Science and Industry Museum and David Govier and the staff of Manchester's Archives+ were generous with their time and knowledge of their collections. Versions of this essay were presented at the 2017 annual symposium of the Society of Architectural Historians of Great Britain and at the 2019 Science Museum Group Research Conference. I have also been ably supported by my colleagues at the Manchester School of Architecture, especially Tom Jefferies, Laura Coucill, and Luca Csepely-Knorr.

"Computer Industry," House of Commons Debates, 1 Mar. 1965, vol. 707, cols. 924-30, https://api.parliament.uk/historic-hansard/commons/ 1965/mar/01/computer-industry (accessed 13 July 2020); Alex D'Agapeyeff, "A Programme for British Computers," Guardian, 16 Mar. 1965, 6.

2. Harold Wilson, speech delivered at the Labour Party's Annual Conference, Scarborough, Oct. 1963, quoted in David Edgerton, "The 'White Heat' Revisited: The British Government and Technology in the 1960s," Twentieth Century British History 7, no. 1 (1996), 56. See also Richard Coopey, "The White Heat of Scientific Revolution," Contemporary British History 5, no. 1 (1991), 115-27.

3. "National Computing Centre," House of Commons Debates, 7 Dec. 1965, vol. 722, cols. 245-51, https://api.parliament.uk/historic-hansard/commons/ 1965/dec/07/national-computing-centre-1 (accessed 13 July 2020).

4. Gabrielle Hecht, The Radiance of France: Nuclear Power and National Identity after World War II (Cambridge, Mass.: MIT Press, 1998), 15. Hecht acknowledges earlier use of the term by Bryan Pfaffenberger in his article "Technological Dramas," Science, Technology, \& Human Values 17 , no. 3 (1992), 282-312.

5. Both types of computation were developed in Manchester. See Simon Lavington, Early Computing in Britain: Ferranti Ltd. and Government Funding, 1948-1958 (Cham, Switzerland: Springer, 2019), 14-17; Jonathan Aylen, "Bloodhound on My Trail: Building the Ferranti Argus Process Control Computer," International Fournal for the History of Engineering \& Technology 82, no. 1 (Jan. 2012), 1-36.

6. The Blue Streak rocket program was developed in secret at Spadeadam in Cumbria, and uranium enrichment, code-named the Tube Alloys Project, began near Mold in North Wales and continued in secret at Capenhurst (Chester), Risley (Warrington), and Springfields (Preston), using equipment manufactured by Metropolitan Vickers at Trafford Park (Manchester) and uranium hexafluoride from Imperial Chemical Industries in Widnes.

7. Martin Dodge, "Governing from the Bunker-Where Would the Government Go after the End of the World?” (2018), 7, https://personalpages.manchester.ac.uk/staff/m.dodge/Dodge-Governing-from-the-bunker-onlineversion.pdf (accessed 28 Nov. 2019).

8. See David Edgerton, Science, Technology and the British Industrial "Decline," 1870-1970 (Cambridge: Cambridge University Press, 1996).

9. Wayne D. Cocroft and Roger J. C. Thomas, Cold War: Building for Nuclear Confrontation 1946-1989 (London: English Heritage, 2003), 237.

10. David Edgerton, Warfare State: Britain, 1920-1970 (Cambridge: Cambridge University Press, 2006).

11. Peter M. Jones, "British Defence Policy: The Breakdown of Inter-party Consensus," Review of International Studies 13, no. 2 (1987), 111-31. This position is apposite with the publicly stated agenda of Wilson's administration and its aim to increase national productivity through investment in civil research and development. In reality, the situation was not so polarized, and preparedness for war was a determining policy feature of all postwar administrations.

12. See Edgerton, Warfare State, 327; Lewis Mumford, Technics and Civilization (New York: Harcourt, 1934).

13. See Robert Bud, "Penicillin and the New Elizabethans," British fournal for the History of Science 31, no. 3 (1998), 305-33; Hecht, Radiance of France. Bud's term "defiant modernism" has been taken up by other historians of technology, such as James Sumner; see, for example, his article "Defiance to Compliance: Visions of the Computer in Postwar Britain," History and Technology 30, no. 4 (2014), 309-33.

14. Jonathan Hogg and Christoph Laucht, "Introduction: British Nuclear Culture," in "British Nuclear Culture," ed. Jonathan Hogg and Christoph Laucht, special issue, British Fournal for the History of Science 45, no. 4 (2012), 482.

15. Jonathan Hogg, British Nuclear Culture: Official and Unofficial Narratives in the Long 20th Century (London: Bloomsbury, 2016), 4.

16. See, for example, John Summerson, "Bread \& Butter Architecture," Horizon: A Review of Literature and Art 6, no. 34 (Dec. 1942), 233-43; Steven Harris and Deborah Berke, eds., Architecture of the Everyday (New York: Princeton Architectural Press, 1998); Ricardo Agarez and Nelson Mota, "Introduction: Architecture in Everyday Life," in "The 'Bread \& Butter' of Architecture: Investigating Everyday Practices," ed. Ricardo Agarez and Nelson Mota, special issue, Footprint 9, no. 2 (Autumn/Winter 2015), 1-8.

17. Reynar Banham, The New Brutalism: Ethic or Aesthetic (London: Architectural Press, 1966), 41.

18. Alistair Fair, Modern Playhouses: An Architectural History of Britain's New Theatres, 1945-1985 (Oxford: Oxford University Press, 2018), 4, 5.

19. Other approaches to this topic have favored study of the planning elites, both those in central government and those in the planning profession. See Otto Saumarez Smith, "Central Government and Town-Centre Redevelopment in Britain, 1959-1966," Historical fournal 58, no. 1 (2015), 217-44.

20. For example, the University Grants Committee oversaw the construction of buildings for higher education. Alistair Fair notes that "the design of schools, housing, and universities remained local matters, albeit ones shaped by central government finance." Alistair Fair, “ 'Modernization of Our Hospital System': The National Health Service, the Hospital Plan, and the 'Harness' Programme, 1962-77," Twentieth Century British History 29, no. 4 (2018), 549.

21. Procurement, in UK construction terms, encompasses all the various activities of a client or employer who seeks the construction of a building.

22. The best comparison for a bespoke government project is Leslie Martin's scheme for Whitehall, but Martin's project differed from the NCC in two key ways: it went unbuilt and its detailed design was not subject to discussion by central or local government. See Adam Sharr and Stephen Thornton, Demolishing Whitehall: Leslie Martin, Harold Wilson and the Architecture of White Heat (Farnham: Ashgate, 2013).

23. Quotes from Walter Bor, "A Question of Urban Identity," in Planning and Architecture, ed. Dennis Sharp (London: Barrie \& Rockliff, 1967), 16. Recent scholarship has turned to commercial architecture and speculative development of the postwar period that was derided in its time and has been largely ignored by architectural historians. See, for example, Ewan Harrison, “ 'Money Spinners': R. Seifert \& Partners, Sir Frank Price and Public-Sector Speculative Development in the 1970s," Architectural History 61 (2018), $259-80$.

24. Henri Lefebvre used the term "abstract rationality" to refer to the articles of the state designed to control the production of space. Łukasz Stanek quotes Lefebvre and expands on this idea by including "the state authority, the developer, [and] the planner" as specific agents of the state. Łukasz Stanek, Henri Lefebvre on Space: Architecture, Urban Research, and the Production of Theory (Minneapolis: University of Minnesota Press, 2011), 142. See also Philippe Boudon, Lived-in Architecture: Le Corbusier's Pessac Revisited, trans. Gerald Onn (London: Lund Humphries, 1972).

25. Ernest Rutherford and Bertram Vivian Bowden, "The $\gamma$-Rays from Actinium Emanation and Their Origin," Proceedings of the Royal Society London A 136, no. 829 (1932), 407-12; Ernest Rutherford, Charles Eryl WynnWilliams, Wilfrid Bennett Lewis, and Bertram Vivian Bowden, "Analysis of $\alpha$-Rays by an Annular Magnetic Field," Proceedings of the Royal Society London A 139, no. 839 (1933), 617-37; Ernest Rutherford, Wilfrid Bennett Lewis, 
and Bertram Vivian Bowden, "Analysis of the Long Range $\alpha$-Particles from Radium C by the Magnetic Focussing Method," Proceedings of the Royal Society London A 142, no. 846 (1933), 347-61.

26. "Proposed Talks on Future of College of Technology: Dr B. V. Bowden to Be New Principal," Manchester Guardian, 27 June 1953, 3.

27. Geoffrey Tweedale, "Bertram Vivian Bowden, 1910-1989," Annals of the History of Computing 12, no. 2 (Apr./June 1990), 138-40.

28. "Proposed Talks on Future," 3.

29. "Scientific Resources (Utilisation)," House of Commons Debates, 5 May 1950, vol. 474, cols. 2060-150, https://api.parliament.uk/historic-hansard/ commons/1950/may/05/scientific-resources-utilisation (accessed 13 July 2020); Marcus Laurence Oliphant, "University or Institute of Technology?," Higher Education Quarterly 4, no. 1 (Nov. 1949), 19-23.

30. The 1963 report of the Committee on Higher Education, known as the Robbins Report, recommended immediate expansion of universities and the granting of university status to all colleges of advanced technology. Committee on Higher Education, Higher Education: Report of the Committee Appointed by the Prime Minister under the Chairmanship of Lord Robbins 1961-63 (London: HMSO, 1963).

31. See, for example, Simon Lavington, Early British Computers: The Story of Vintage Computers and the People Who Built Them (Manchester: Manchester University Press, 1980); Kenneth Flamm, Creating the Computer: Government, Industry, and High Technology (Washington, D.C.: Brookings Institution, 1988); Michael Campbell-Kelly and William Aspray, Computer: A History of the Information Macbine (New York: Basic Books, 1996); John Hendry, Innovating for Failure: Government Policy and the Early British Computer Industry (Cambridge, Mass.: MIT Press, 1989); Simon Lavington, Moving Targets: Elliott-Automation and the Dawn of the Computer Age in Britain, 1947-67 (London: Springer, 2011).

32. D. Johnson, "What Manchester Did Yesterday," Guardian, 15 Dec. 1975, 5. 33. Freddie Williams, interview by Paul Drath, 29 June 1972, cited in Paul Drath, "The Relationship between Science and Technology: University Research and the Computer Industry 1945-1962" (PhD diss., University of Manchester, 1973).

34. Professor Newman, report to the Buildings Committee, 15 Oct. 1948, Minutes of the Building Committee, vol. 1, 1946-58, 90, GB 133 USC/4/1, Archive of the University of Manchester.

35. Simon Lavington, A History of Manchester Computers (Manchester: NCC Publications, 1975).

36. As well as Edgerton's treatise Warfare State, see Matthew Grant, After the Bomb: Civil Defence and Nuclear War in Cold War Britain, 1945-68 (London: Palgrave Macmillan, 2009).

37. Edgerton, Warfare State, 106.

38. The government paid Ferranti approximately $£ 175,000$ over five years to build this machine. Lavington, Early British Computers, 26.

39. Correspondence, National Research Development Corporation to Professor Sir David Brunt of Imperial College, member of the Research Advisory Committee on Computing, DSIR 10/343, National Archives, London (hereafter NA).

40. Faster Than Thought was Bowden's attempt to write U.S. competitors out of the history of computers; it was the first to book to present Charles Babbage as the father of computation. B. V. Bowden, ed., Faster Than Thought: A Symposium on Digital Computing Machines (London: Sir Isaac Pitman \& Sons, 1953). See also Sumner, "Defiance to Compliance."

41. Blackett, also a government and military adviser, "was a forceful advocate of university expansion and government funding of research and development." Mary Jo Nye, "Blackett, Patrick Maynard Stuart, Baron Blackett (1897-1974)," Oxford Dictionary of National Biography, http://www. oxforddnb.com/view/article/30822?docPos=1 (accessed 8 Jan. 2015). His role in the Wilson administration and the creation of the Industrial Reorganisation Corporation (IRC) is explored in Maurice W. Kirby, "Blackett in the
'White Heat' of the Scientific Revolution: Industrial Modernisation under the Labour Governments, 1964-1970," Fournal of the Operational Research Society 50, no. 10 (Oct. 1999), 985-93.

42. For a reenactment of the speech, see "Harold Wilson's 'White Heat' Speech Re-enacted, 50 Years On," Guardian, 1 Oct. 2013, http://www.theguardian.com/politics/political-science/2013/oct/01/harold-wilson-whiteheat-speech-live (accessed 8 Aug. 2014).

43. Wilson's remarks mimicked advice that Patrick Blackett had given to Labour Party leader Hugh Gaitskell prior to the 1959 general election. Science and technology did not feature prominently in the 1959 campaign, as Gaitskell feared that emphasizing them would expose divisions within the party.

44. Harold Wilson, The New Britain: Labour's Plan Outlined by Harold Wilson (London: Penguin, 1964), 9, quoted in Sharr and Thornton, Demolishing Whitehall, 8.

45. Jim Tomlinson, "Conservative Modernisation, 1960-64: Too Little, Too Late?," Contemporary British History 11, no. 3 (1997), 18; Sharr and Thornton, Demolishing Whitehall, 9.

46. Murray Laver, "ICL-The Ministry of Technology (MinTech) and the Merger," Contemporary British History 13, no. 1 (Spring 1999), 183-85.

47. Flamm, Creating the Computer, 5, 29-75.

48. Edgerton, Warfare State.

49. Grant, After the Bomb.

50. The IRC's function was to promote the efficiency and competitiveness of British industry by encouraging firms to merge into larger units in service of the national interest. Douglas C. Hague, The IRC: An Experiment in Industrial Intervention-A History of the Industrial Reorganisation Corporation (London: Unwin Hyman, 1983).

51. Edgerton, Warfare State, 105.

52. Reinhold Martin, The Organizational Complex: Arcbitecture, Media, and Corporate Space (Cambridge, Mass.: MIT Press, 2003).

53. This was contrary to the attitude in the U.S. computer industry, where outsourcing and subcontracting were common practices.

54. By the late 1960s, a plethora of other research establishments were in operation, including the National Physical Laboratory, the UKAEA research and reactor groups, and others set up to study water, hydraulics, fire, engineering, armament, rocket propulsion, and more. For a full list, see Edgerton, Warfare State, 248, table 6.1.

55. Lavington, History of Manchester Computers, 5.

56. Royal Society, Minutes of the Council, 1945-48, vol. 17, quoted in Lavington, 4. On Williams's method of using cathode-ray tubes to store information and, in effect, creating the first random-access memory, or RAM, storage device, see Drath, "Relationship between Science and Technology."

57. The building still stands on Coupland Street on the University of Manchester campus. TRE information from Newman, report to the Buildings Committee, 90. Information about the lack of steel in the building's construction comes from Simon Lavington, personal communication with author, 20 Aug. 2014.

58. Geoffrey Tweedale, "A Manchester Computer Pioneer: Ferranti in Retrospect." IEEE Annals of the History of Computing 3 (1993), 37-43.

59. Time, 7 Jan. 1966, cited in Peter James Carter, Mies van der Rohe at Work (New York: Praeger, 1974), 172.

60. The conservative appearance of the University of Manchester buildings constructed in the late 1950s and early 1960s led the city council to intervene and commission a master plan for the entire education precinct along Oxford Road. See Richard Brook, Manchester Modern: The Shape of the City (Research Award Report, 2012), ReAw/Brook, RIBA Library. For Mies's projects published in Europe, see Architectural Design, Oct. 1951, 287; L'Architecture d'Aujourd'bui, nos. 50-51 (1953), 26-27; Casabella, no. 214 (1957), 5-19; Bauen \& Wobnen, no. 9 (1959), 317-19.

61. "The Computer Center: New Building Type?," Architectural Record, Nov. 1964, 153-55. The Westinghouse facility was an extension of Noyes's larger 
corporate design package. To help advertise the building's patron, the architects wanted a "vigorous exterior, which would be seen and identified by cars passing by on the highway" (154).

62. Herbert Beckhard, "The Breuer-Beckhard Precast Facades," in Exterior Wall Systems: Glass and Concrete Technology, Design, and Construction, ed. Barry Donaldson (Philadelphia: American Society for Testing and Materials, 1991), 154-69.

63. IBM's policy was to situate the company's brainpower outside large population centers. "Laboratories and Offices," Architects' Fournal Information Library, 12 Feb. 1964, 371-82.

64. "IBM Pilot Head Office, Cosham, Hants.; Architects: Foster Associates," Architectural Design, Aug. 1971, 474-78; "Two Office Buildings: (1) IBM Pilot Head Office Building, Cosham; (2) Computer Technology, Hemel Hempstead; Architects: Foster Associates," Design, Oct. 1971, 54-61; "Two IBM Office Buildings. 1, Offices and Factory, Havant, Hants; Architects: Arup Associates. 2, Offices, Cosham, Hants; Architects: Foster Associates," Architectural Review, Jan. 1972, 4-24.

65. The McMahon Act determined how the United States controlled and managed the nuclear technology it had developed jointly during World War II. The law's restrictions on access to nuclear research created a rift between the United States and its allies, particularly Britain and Canada, and eventually led to Britain's decision to develop its own nuclear arsenal.

66. Cabinet papers, CAB 24-/55/82, NA.

67. Gary Willis, "Fields into Factories: The Impact on the Post-war Rural Landscape of Britain's Second World War, 1936-1946" (paper presented at the conference "Rural Modernism," Northumbria University, 1-2 Aug. 2019).

68. Julian Garratt, "Atomic Spaces North West England 1945 to 1957” (MSc thesis, University of Manchester, 2016), 8.

69. "A Man of Energy to Put Drive into Computers," Times (London), 9 Dec. $1965,5$.

70. M. Razey, "The Universities Research Reactor," Electronics and Power 10, no. 10 (Oct. 1964), 372-73.

71. "National Computing Centre Gets Under Way," Times (London), 26 May $1966,19$.

72. George Hawthorne, "Setting Up Company to Run National Computer Centre," Guardian, 24 May 1966, 4.

73. "Plans for Computer Centre," Guardian, 13 Nov. 1965, 14.

74. "National Computing Centre," House of Commons Debates.

75. Manchester Corporation was the municipal body, governed by a city council, that controlled everything in Manchester, from sanitation to education. John Millar, "Proposed Erection of the Second Phase of the National Computing Centre, Oxford Road and Mancunian Way," app. 7, Town Planning and Building Committee Minutes, 29 May 1969, minute book no. 71, 940-41, GB127, Council Minutes/Town Planning and Buildings Committee/2/71, Archives+, Manchester Central Reference Library.

76. Millar, 940.

77. Rowland J. Nicholas, City of Manchester Plan 1945 (Norwich: Jarrold \& Sons, 1945).

78. Richard Brook and Martin Dodge, Infra_MANC: Post-war Infrastructures of Manchester (Manchester: bauprint, 2012).

79. In the United Kingdom, higher education refers to university-level study, usually from the age of eighteen. Further education typically refers to study that takes place between the ages of sixteen and eighteen.

80. R. A. Thompson, Ministry of Technology, letter to A. E. Drake, UKAEA, 12 Jan. 1966, UKAEA green folder marked "Construction of National Computing Centre (Manchester),” AB 42/38, NA.

81. Brocklesby was also charged with negotiating lease agreements for the site on behalf of Manchester Corporation and the University Grants Committee. UKAEA green folder marked "Construction of National Computing Centre (Manchester)," AB 42/38, NA. Building control plans were deposited on
2 July 1966 and approved on 12 July 1966. Plan nos. 65124, orange card folder, Archives+, Manchester Central Reference Library.

82. Hawthorne, "Setting Up Company," 4.

83. J. Cooper, letter to Mr. F. A. Tatford, UKAEA, undated, UKAEA green folder marked "Construction of National Computing Centre (Manchester)," $\mathrm{AB} 42 / 38$, NA.

84. Hawthorne, "Setting Up Company," 4.

85. R. D. Alyward, Ministry of Technology, letter to H. S. Lee, Treasury, 23 July 1968, T224/1946, NA.

86. T. H. Stables, Ministry of Technology, letter to W. G. E. Morton, Treasury, 1 April 1969, T224/1946, NA.

87. H. S. Lee, Treasury, letter to F. J. M. Laver, Ministry of Technology, 26 April 1968, T224/1946, NA.

88. Lee to Laver.

89. R. D. Alyward, Ministry of Technology, letter to P. L. Dyer, Treasury, 28 Feb. 1968, T224/1946, NA.

90. Building Design Partnership (BDP) established its Manchester office in 1961; the firm of Leach Rhodes Walker was formed in 1954.

91. Biographical information on Cruickshank comes from "Obituary of Herbert William Cruickshank," RIBA fournal, 23 Nov. 1935, 104; "Basic Biographical Details: Herbert William Cruickshank," Dictionary of Scottish Architects, http://www.scottisharchitects.org.uk/architect_full.php?id=203467 (accessed 18 Feb. 2012); John Sheard, interview by author, 5 Aug. 2011, Torquay. John Sheard worked as an architectural assistant for Cruickshank \& Seward, 1957-60. He spent five years with Wilson Womersley and returned to C\&S in 1965. He became a partner in the firm in 1975 and spent the rest of his career with $\mathrm{C} \& \mathrm{~S}$.

92. Gordon Hodkinson, interview by author, 1 Oct. 2012, Hale. Gordon Hodkinson spent his entire career as an architect with Cruickshank \& Seward. He was Arthur Gibbon's principal assistant and went on to be a partner in the firm.

93. Sheard, interview; Hodkinson, interview.

94. Notable among these firms were Gillespie, Kidd \& Coia and Lyons Israel Ellis. See Johnny Rodger, ed., Gillespie, Kidd \& Coia: Architecture 1956-1987 (Glasgow: RIAS in partnership with the Lighthouse, 2007); Neave Brown et al., Lyons Israel Ellis Gray: Buildings and Projects 1932-1983 (London: Architectural Association, 1988).

95. Southport Technical College, Opening of New Building 1935: Programme (1935), S379.4272 SOU, Crosby Library, Merseyside.

96. The two other partners were Lee Monks and Ken Howarth. For biographical information on Gibbon, see "Gibbon, William Arthur," Lit \& Phil Card Index, Manchester Literary and Philosophical Society, http://cardindex. manlitphil.ac.uk/cards/1176 (accessed 2 Aug. 2017). A biographical description of John Seward from his time on the Royal Institute of British Architects Council is held on file at the RIBA Library.

97. Sheard, interview.

98. See Richard Brook, "Manchester Chapels," C20: The Magazine of the Twentieth Century Society, Spring 2011, 29. See also "St. Peter's House University Chaplaincy, 1976," Mainstream Modern, http://www.mainstreammodern.co. uk/casestudies.aspx/Detail/141/st-peters-house-university-chaplaincy (accessed 29 Nov. 2019); and, regarding an unbuilt scheme at Manchester Airport, "International Centre, Ringway, Manchester," Architectural Review, Jan. 1973, 11.

99. Sheard, interview.

100. "Premier to Open Mancunian Way," Guardian, 16 Mar. 1967, 18.

101. Sheard, interview. A similar account, from a conversation in which John Sheard was involved, is recorded in J. J. Parkinson-Bailey, Manchester: An Architectural History (Manchester: Manchester University Press, 2000).

102. F. J. M. Laver, director of Computer Division, Ministry of Technology, letter to "Leo," 15 June 1967, T224/1418, NA.

103. Millar, "Proposed Erection of the Second Phase." 
104. The design went unbuilt in favor of one prepared by in-house BBC architect R. A. Sparkes. The idea of vertical separation between pedestrians and traffic informed Wilson Womersley's approach to planning the Education Precinct; see Hugh Wilson and Lewis Womersley, Manchester Education Precinct: The Final Report of the Planning Consultants 1967 (Manchester: Corporation of Manchester, 1967).

105. Ministry of Technology Computer Policy based on minister's statement to the House, 1 Mar. 1965, FV 49/2, NA.
106. National Computing Centre, Conference Facilities at the Centre (pamphlet) (Manchester: NCC, 1976).

107. Edgerton "The 'White Heat' Revisited," 80.

108. Adrian Forty, "Appendix: Outcomes from the Liverpool Workshop 2012," in Architecture and the Welfare State, ed. Mark Swenarton, Tom Avermaete, and Dirk van den Heuvel (London: Routledge, 2015), 322. Forty presents lists of issues and questions drawn up at the conclusion of the workshop "as pointers for future research." 